\title{
Alguns fragmentos para arquivar uma coleção*
}

Gedley Belchior Braga *

BRAGA, G.B. Alguns fragmentos para arquivar uma coleção. Revista do Museu de Arqueologia e Etnologia, São Paulo, 19: 309-335, 2009.

Resumo: Este artigo apresenta uma série de reflexões sobre "coleções", "colecionismo" e sobre o sujeito chamado "colecionador", baseadas principalmente na idéia de "desconstrução", do filósofo Jacques Derrida.

Palavras-chave: Coleção - Colecionismo - Colecionador - Arquivo Arqueologia cognitiva - Derrida - Narrativas sobre a construção da linguagem - Arte contemporânea - Post scriptum.

"O fragmento é um mestre da escola das artes fictícias". André Malraux (2000)

(...) "havia nele uma sedução pelo fragmento, pela ruptura, e uma tentação de reconstituir um conjunto, uma continuidade cósmica". Jean Baudrillard (2003)

1 Quem pensa em constituir uma coleção, talvez queira arquivar uma história. Talvez uma história que não seja possivel ser contada apenas por meio de palavras em um texto escrito e impresso. Cada

$\left({ }^{*}\right)$ O conteúdo deste artigo é adaptado do segundo capítulo da tese de doutorado "A tese na [da] caixa preta", de minha autoria, defendida em maio de 2008, na Escola de Comunicações e Artes da Universidade de São Paulo [ECA/USP].

$\left.{ }^{* *}\right)$ Departamento de Arquitetura, Urbanismo e Artes Aplicadas da Universidade Federal de São João del-Rei DAUAP/UFSJ.gedley@uol.com.br peça dessa coleção, desse arquivo chamado coleção, é um fragmento de uma narrativa textual impossível. Entre o "visto" e o "não visto", entre o visível e o invisível, entre o subjetivo e o objetivo, estão centenas, milhares, ou até milhões de possibilidades de combinação, leitura e interpretação. Os objetos dessa coleção podem ser âncoras, pontos de passagem, locais onde fixar a atenção por algum tempo. Também poderiam ser vistos como documentos [evidências] que possibilitam reinterpretações e reconstruções de uma trajetória e duração de uma vida, de um pensamento. Podem ser utilizados como as 
provas dos fatos narrados, quando se requisita a existência de algo com a devida consistência física como evidência incontestável que pode ser chamada de "prova de alguma coisa". Sob o ponto de vista do colecionador, além do interesse, do gosto e do prazer envolvidos no processo, os objetos podem conter narrativas diversas que transcendem os limites de comunicação entre o dizível e o não dizível. Entre todas as coisas disponíveis em um "mundo de coisas" [que o "espírito de Heidegger" convoca], uma coleção revela circunstâncias para se falar sobre o ser e o mundo. E sobre tudo o que pode ser dito, ainda é necessário lembrar que muita coisa se perde nas cinzas de um arquivo apagado (Derrida 1990).

2. A palavra arquivo nomeia um começo, e simultaneamente um comando de um lugar onde as coisas começam. Existe no começo e no comando - gênese (Derrida 2005c) um local khora (Derrida 1995) de onde se exerce uma autoridade, para o bem ou para o mal (Derrida 2005b), a partir do qual uma ordem é dada (Derrida 2001). Essa origem talvez esteja localizada em um "Ser". Um "ser" positivo confrontado a um "nada" negativo, enfim, na própria existência do ser que encara suas percepções [ou sua fé perceptival como participantes de um mundo efetivo de experiências e ações (Merleau-Ponty: 2003). ${ }^{1}$ Esse "ser" parte do princípio de uma realidade do ser que não é desvinculada de seu pensamento, admitindo-se todas as possibilidades de contradições de um pensamento inevitavelmente envolvido naquilo que se qualificam como "fé perceptiva”, incluindo suas obscuridades, reflexões, negações, interrogações e intuições (idem).

3. Do grego Arkhê (começo e comando), assim como no latim archivum ou archium, o sentido do arquivo remete ao arkheion grego, um domicílio, endereço, residência dos magistrados superiores, os arcontes, aqueles que comandavam, que eram os guardiões do arquivo, mas que também tinham o poder de

(1) A fé perceptiva e a negatividade, reflexões de MerleauPonty (2003: 57-96). interpretá-los. Os arquivos precisavam ter uma consistência física [não há arquivo sem exterior], um suporte e uma residência que estabeleçam uma autoridade hermenêutica legítima (Ricoeur: 2008). Uma teoria do arquivo propõe com seus títulos, gêneses e genealogias uma consignação como uma reunião de signos em um determinado local cuja legalidade ou legitimidade determinam limites do direito: direito das famílias ou do Estado. Esses limites estabelecem relações entre o secreto e o não secreto, um trânsito entre o privado e o público, entre o autobiográfico e o biográfico, são também representações de "estratégias fatais" entre "trocas impossíveis" (Baudrillard 2002; 2006). Para Derrida, a psicanálise produziu um efeito devastador sobre o arquivo, sobre o local em que se inscreve a palavra arquivo e sobre a autoridade que se exerce em seu nome. Não há mais ordem alguma garantida, pois a impressão da psicanálise deixou uma assinatura freudiana sobre o conceito de arquivo e de arquivamento, "o que é o mesmo que dizer, inversamente e por contragolpe, sobre a historiografia" (Derrida 2001: 11-16).

4. O "mal de arquivo", de Derrida, remete a uma desconstrução e reconstrução da psicanálise freudiana como uma ficção de uma espécie de pulsão de morte, de destruição na economia da produção do arquivo. Essa pulsão trabalha para destruir o arquivo no local onde existe uma falta originária e estrutural da chamada memória. O medo da aniquilação da memória ou do esquecimento produz a consignação do dispositivo documental ou monumental sobre algum suporte e em um lugar exterior. A estrutura técnica do arquivo arquivante determina também a estrutura do conteúdo arquivável em seu próprio surgimento e em sua relação com o futuro. $\mathrm{O}$ arquivamento tanto produz quanto registra o evento (Derrida 2001: 22-29). Importante reter aqui que existe, na origem de um arquivo, uma possibilidade de "simultaneidade" na produção e no registro de um evento. $\mathrm{O}$ evento aqui deve ser visto como o acontecimento arquivável que tem a necessidade de uma consistência, um exterior com fronteiras entre o dentro e o fora. $\mathrm{O}$ acontecimento post-scriptum determina retrospectivamente o que o precede. A pulsão 
de destruição incorpora a pulsão de conservação, o que Derrida chama de "pulsão de arquivo" [ou "compulsão"]. O acontecimento arquivável depende simultaneamente de uma instabilidade transitória entre passado e futuro. $\mathrm{O}$ arquivo remete ao passado, mas depende do conceito de futuro, pois está em débito com a história do conceito que inscreve uma impressão na língua e no discurso, articula o desejo, sua abertura para o futuro, "em suma, tudo o que liga o saber e a memória à promessa" (Derrida 2001: 45). Portanto, quando se arquiva algo, há um compromisso, uma promessa de se preservar um elo como uma "herança" [ou memória] do agente que produziu a "necessidade" de determinado arquivamento de uma coisa.

5. $\mathrm{O}$ arquivista produz o arquivo. Ele está em uma situação de "injunção 'arcôntica' de proteger e recolher o arquivo, lembrar dos outros, os outros do outro e os outros em si" (Derrida 2001: 99). Em uma lógica do inconsciente relacionada com um pensamento virtual, a interpretação do arquivo está às voltas com as instâncias freudianas da verdade histórica versus a verdade material. São duas fontes contraditórias que dependem da declaração, ou melhor, de uma confissão. Mas a verdade não está em lugar algum. A verdade é espectral e fantasmática e todas as situações podem conter uma semente de verdade da verdade, de acordo com o pensamento arqueológico que é resgatado pelo pai da psicanálise. Uma arqueologia está sempre em tensão com sua evidência material. A tensão e atenção voltadas para a decifração do desejo interior de decifrar. E nessa tensão é possivel encontrar-se com fantasmas e até falar com eles. ${ }^{2}$ Assim, "a experiência através da qual

(2) Derrida cita a aparição espectral do pai de Hamlet, como o prenúncio da chegada de um scholar do futuro, que "no futuro, e para pensar o futuro, ousaria falar com o fantasma. De um scholar que ousaria confessar que ele sabe falar com fantasmas, pretendendo mesmo que isso não contradiga nem limite sua "scholarship" mas que, ao contrário, a tenha condicionado à custa de alguma complicação ainda impensada que viesse dar razão ao outro, isto é, ao fantasma. E talvez sempre ao fantasma paterno, isto é, aquele que está em posição de ter razão, de se dar razão - e de dar sempre a última palavra”. (Derrida 2001: 54). encontramos os fantasmas ou os deixamos vir a nosso encontro é indestrutível e inegável" (idem, p. 115). No entanto, Freud não se exclui do perigo e nem omite os grandes riscos da ficção envolvida em todos esses processos [e o próprio Derrida se inclui no mesmo raciocínio]. Isso não elimina o fato de que "o primeiro arquivista institui o arquivo como deve ser, isto é, não apenas exibindo o documento, mas estabelecendo-o. Ele o lê, interpreta e classifica" (ibidem, p.73). Poeticamente ele o coloca na "Arca da Aliança" e estabelece um princípio de crença, praticamente como um imperativo religioso [mais uma vez, uma "promessa"] de lembrar de se lembrar.

6. A perturbação do arquivo é a perturbação dos segredos, dos complôs, dos assuntos perturbantes que perturbam e turvam a visão, que impedem o ver e o saber, em meio às conspirações clandestinas, às conjurações meio privadas, meio públicas, sempre no limite instável entre o público e o privado e uma intimidade mais privada que a família, entre si e si (Derrida 2001: 117). O arquivo reserva sempre um problema de tradução. Para Derrida, os fantasmas são muito sensíveis às leis do idioma. O mal de arquivo é também uma "febre de arquivo”, como o título da tradução inglesa da obra de Derrida (1996), é arder de paixão, é não ter sossego, é "incessantemente, interminavelmente procurar o arquivo onde ele se esconde. $\dot{E}$ correr atrás dele ali onde, mesmo se há bastante, alguma coisa nele se anarquiva [ou seja, algo no arquivo é sempre impossível de ser arquivado]. É dirigirse a ele com um desejo compulsivo, repetitivo e nostálgico, um desejo irreprimível de retorno à origem, uma dor da pátria, uma saudade de casa, uma nostalgia do retorno ao lugar mais arcaico do começo absoluto. Nenhum desejo, nenhuma paixão, nenhuma pulsão, nenhuma compulsão, nem compulsão de repetição, nenhum "mal de", nenhuma febre surgirá para aquele que, de um modo ou outro, não está já com mal de arquivo" (Derrida 2001: 118-119). A procura desse lugar "mais arcaico do começo absoluto" remete ao "até um momento" de "impressão" de uma "arqueologia”.

7. Pois é esse "até um momento" cuja expressão é de uma "impressão" que é muito 
difícil de ser arquivada. De qual momento se fala sobre um determinado momento? Poder-seia inverter a questão e propor a partir de qual momento se lêem as impressões de um acontecimento presente? O sentido literal de uma data se inscreve em uma coleção como algo arquivável? Seria uma determinada "data" uma tese arquivável? Não são as datas referenciais para as experiências da memória, assim como para a utilização dos termos "arcaico" ou mesmo "arqueológico"? Esse "até o momento" coloca uma busca por um tempo perdido, a constituição [ou tentativa de reconstituição] de uma instância e de um lugar de autoridade. Uma condição para se resgatar a originalidade [no sentido de "origem"] de um acontecimento. Ou seria a própria duração de um acontecimento que estaria em jogo? Uma duração "até o momento" poderia supor uma originalidade como uma unicidade? De acordo com Derrida, essa unicidade pode não resistir. "Seu preço é infinito. Mas infinito na medida imensa, incomensurável onde é inencontrável. A possibilidade do traço arquivante, esta simples possibilidade, não pode senão dividir a unicidade. Separando a impressão da marca. Pois esta unicidade não é nem mesmo um presente passado. Ela não teria sido possivivel, só podemos sonhar, a posteriori, na medida em que sua iterabilidade, isto é, sua divisibilidade permanente, a possibilidade da sua fissão a obcecava desde a origem. A memória fiel de uma tal singularidade só pode ser entregue ao fantasma. [...] A propósito desta contabilidade secreta, podemos sonhar. A especulação começa aí - e a fé. Mas o segredo propriamente não pode ter arquivo, por definição. O segredo são as cinzas do arquivo, o lugar onde não tem mais sentido dizer as 'próprias cinzas' em sobre as 'cinzas'." (Derrida 2001: 128).

8. Um desafio a enfrentar é tentar se aproximar da literalidade dos acontecimentos. Como transformar a decisão de arquivar uma coleção em um texto? Como adequar o conteúdo dos acontecimentos de uma coleção a uma determinada forma escrita? Talvez, a melhor alternativa seja utilizar o próprio raciocínio de uma coleção. Ela não seria um conjunto, um agrupamento de coisas? A princípio, tais coisas teriam alguma razão, alguma conexão apenas para quem as colecionou. Aos olhos dos outros, tais objetos colecionados não deixariam de ser várias coisas simultâneas colocadas paralelamente umas às outras. O termo "paralelamente" aqui não deixaria de ser uma alusão a uma possibilidade de tal coleção. Mas, espacialmente falando, se as peças estivessem realmente paralelas umas às outras, apenas se poderia ver aquelas que estivessem nas extremidades dessa fila. Talvez fosse possivel ver as bordas das obras que constituíssem tal coleção. Para fugir da armadilha do termo "paralelamente", seria melhor dizer que as obras podem ser simultâneas em um determinado agrupamento. E se elas fossem expostas simultaneamente, justapostas lado a lado em uma mesma e imensa parede, poderiam simular uma linha de lateralidade e vizinhança. Poderia dissimular um efeito paralelo ao trabalho de uma escrita que justapõe letras, palavras, enfim, frases justapostas e sobrepostas unindo as experiências da horizontalidade com a verticalidade, ou melhor, constituindo-se como um corpo de uma obra horizontal que, por motivos óbvios de clareza são pontos de uma linha que, se não fosse fragmentada, poderia se estender ad infinitum. $\mathrm{O}$ texto, a escritura.

\section{A estratégia fragmentária parece ser a} melhor alternativa para acompanhar o raciocínio de formação de uma coleção. A fragmentação literal do texto permite a reprodução formal de um efeito de acumulação de outros pequenos textos e suas unidades mínimas gramaticais. A vontade de acumulação pode representar ou poderia tentar disfarçar outra intenção: a ação de enfrentar o vazio e o desaparecimento. Vazio e desaparecimento: duas palavras caras aos colecionadores. $\mathrm{O}$ vazio é preenchido com a busca e a acumulação de objetos cujo sentido último poderia estar nos domínios do desaparecimento do sujeito e das próprias coisas. $\mathrm{O}$ ser e o nada.

10. A coleção, em outra vertente também passível de estudos históricos, artísticos, etnográficos e antropológicos, deixa de tratar do universo paralelo ou circundante para se ocupar com o objeto/causa/origem/finalidade 
de existência de um sistema de legitimação dessas coisas. Essa coleção pode ser entendida como a constituição de um espaço de jogo cuja única singularidade, o seu criador / colecionador, é quem irá ditar as regras. "A coleção emerge para a cultura: visa objetos diferenciados que têm freqüentemente valor de troca, que são também "objetos" de conservação, de comércio, de ritual social, de exibição, - talvez mesmo fonte de benefícios. Estes objetos são acompanhados de projetos. Sem cessar de se remeterem uns aos outros, incluem neste jogo uma exterioridade social de relações humanas" (Baudrillard 1993:111). Essa exterioridade social de relações humanas age em momentos distintos e múltiplos. Um projeto de tal natureza não seria ingênuo ao ponto de não imaginar e supor que, a partir de determinado ponto, seu silêncio, sua invisibilidade e/ou indiferença deixariam de existir. $\mathrm{O}$ inventário total de um arquivo formado por uma coleção poderia mostrar que essa ingenuidade não existe. Ao mesmo tempo, essa falta de ingenuidade supõe a própria contradição de que não se deve e não se pode abrir todo o arquivo sob o risco de afetar toda essa rede de relações humanas, suas táticas e estratégias que requerem compromissos de segredos e silêncios.

11. Uma coleção arquivada poderia ser considerada "um acontecimento"? Uma coisa aconteceu e acontece ainda. Uma coisa pode parecer infinita enquanto sua origem persiste em existir. Nota-se aqui uma possibilidade de efeito de sucessão, de encadeamento, de ordenamento, de exposição, enfim, de arquivamento. A influência do pensamento de Derrida é inegável, pois o que está em ação aqui são as complexas máquinas de produção da escrita e do próprio arquivamento. Se a invenção pode ser considerada um acontecimento (Derrida 2004: 70), diz-se que o acontecimento afeta o "quem" e o "quê". Uma coleção é o resultado de um afeto, mas sua concretização, sua invenção como corpo, como um agrupamento, como um novo conjunto que antes não existia, afeta o próprio colecionador e potencialmente pode atingir também um outro "quê". Esse outro "quê" pode refletir o potencial de relações aberto por algo que não existia antes.
Pode ser representado pelo próprio sistema de legitimação do conhecimento que acaba reagindo à força de união de elementos que antes se encontravam dispersos. O acontecimento afeta e transforma as singularidades de todo o tipo, ainda que seja a título de um acontecimento passado, inscrito ou arquivado (idem, p. 80), intencionalmente, deliberadamente ou mesmo de propósito (ibidem, p. 91).

12. A coleção, como uma construção, sempre oferece a oportunidade de uma operação de desconstrução. Se a coleção for vista dentro da perspectiva de uma invenção, ela também pode ser um acontecimento. A desconstrução de um acontecimento, portanto, envolve uma operação. Para operar a desconstrução do corpo de uma coleção é necessário o instrumental adequado, talvez até a utilização de instrumentos cirúrgicos e máquinas. A desconstrução do corpo ameaça o sujeito autobiográfico, pois a sua construção geralmente foi feita com a apropriação de diversos elementos nem sempre esclarecidos durante sua existência subjetiva. As apropriações de idéias podem sugerir furtos, roubos, enganação, mentira, simulação e dissimulação [como no sistema artístico, um novo "corpus delicti"?]3. Como o próprio corpo humano, tal construção pode ser forte em seu conjunto e muito frágil se analisada sob aspectos microscópicos.

13. O fim de uma obra pode ser sua origem. A finalidade de uma coleção pode ser o relato de uma experiência, o comentário, a confissão, o arquivo. Não existe acontecimento sem uma experiência que o tenha antecedido. Derrida diz que um acontecimento apenas advém se sua irrupção interrompe o curso do possível e como o impossível surpreende toda a previsibilidade (Derrida 2004: 38). O maior problema é provar que houve um acontecimento, principalmente quando a única fonte testemunhal e o único arquivista do aconteci-

(3) Obra da artista plástica Jac Leirner, "Corpus delicti" era constituída inteiramente de peças furtadas de aeronaves, durante os trajetos percorridos pela artista. 
mento estão conjugados em um mesmo sujeito. Trata-se de um universo em que o relato pode estar próximo de uma confissão. O território é aquele em que são obscuras as relações entre acontecimento, memória, memória mecânica ou não, arquivo, consciência e inconsciente, um delicado e abissal problema de arquivamento (idem, p.48).

14. A maior matéria-prima do colecionador é o tempo. Somente o tempo permite a constituição do conjunto que receberá o nome de coleção. Adaptando livremente o que Derrida escreveu em outro contexto, trata-se de um tempo de "cedo ou tarde" que se procede ao fenômeno "de graça", de um "estado de graça". Explicando melhor, é o tempo necessário para que um conjunto de coisas separadas [fragmentos] se transforme em um corpo, e esse corpo em uma obra [coleção]. O produtor de um arquivo chamado "coleção", assim como o artista, espera sua redenção em um tempo que pode estar além de sua própria vida. Não deixa de ser um sonho muito ambicioso que pode depender de uma série de acasos. Mas o que seria do ser humano sem incorrer aos afetos que envolvem ambições que pudessem escapar à sua capacidade de controle? E nas mãos de quem estaria esse controle? Somente o tempo pode fazê-lo crer e esperar que sua obra passe a operar por si mesma, para muito além e sem a assistência viva de seu signatário, qualquer que seja o tempo necessário, qualquer que seja o tempo por vir; pois o tempo não deve contar mais com a sobrevivência de um "cedo ou tarde”: nesse caso, a operação do sentido literal de algo "póstumo" é inevitável. Nessa perspectiva, pouco importa o tempo que isso levará, o tempo é dado, ele está do lado de quem alcançou "a graça" e não existe mais como um referencial. O tempo não custa mais nada. Não se está mais diante do domínio do circuito econômico. Como não custa mais nada, esse tempo é dado graciosamente em troca do trabalho da obra que opera sozinha, quase maquinalmente, virtualmente, e, portanto, sem trabalho do autor: como se, contrariamente ao que muitas vezes se pensa, houvesse entre a graça e a máquina, entre o coração e o automatismo da marionete, uma invencível afinidade; como se ela funcionasse sozinha, a máquina de desculpar, como máquina de escrever e, ao mesmo tempo, de inocentar (Derrida 2004: 51).

15. Uma coleção pode propor o pensamento sobre a lógica do acontecimento textual como inscrição material. $\mathrm{O}$ acontecimento textual remete à história e à historicidade da história. Pode-se pensar no conceito de história a partir de uma lógica que é regulada pela análise posterior do acontecimento, da ocorrência e da singularidade de um evento. Uma lógica retrospectiva, portanto, retroativa, e que muitas vezes oculta o valor do poder de quem narra; a linguagem do poder e a linguagem como poder. $\mathrm{O}$ materialismo da coleção possibilita um jogo de significações em que apenas a noção do tempo não basta para fazer história. Está certo que a coleção é formada de fragmentos descontínuos. No entanto, a materialidade mesma da inscrição ou do "rastro material" constituído permite que as coisas possam ser sempre restauradas, recuperadas, "reinscritas" em um sistema cognitivo.

16. No ato de colecionar pode estar implícita outra operação: a coexistência de uma representação político autobiográfica de uma vida e uma época. Pode existir nessa operação de escrita a intenção de arquivar um retrato de uma vida. O colecionador, assim como um artista, estaria acumulando matéria-prima para um auto-retrato póstumo. Não se pode falar em inserção de vida e autobiografia sem o aparecimento de um contexto político. Se o que está em jogo é a construção de um retrato, essa imagem não será apenas a de um "ser autobiográfico” em um fundo branco ou neutro, nem que esse fosse o seu único e exclusivo objetivo. Todos os outros componentes do cenário dessa fotografia irão inevitavelmente estar presentes. Ao colecionar alguma coisa característica de uma época é preciso lembrar a importância da materialidade daquilo que se coleciona e também da presença da palavra época, além de todas as operações que isso pode implicar. Uma coleção escreve ou inscreve um arquivo para a 
sua própria época. Ela revela o engajamento [ou abnegação?] de uma vida preocupada em se inserir no contexto de sua época. E o engajamento aqui é a operação que se revela como se fosse uma intimação a que e pela qual atendem alguns seres que optam, em qualquer circunstância, pela vida. ${ }^{4}$

17. A inteligência presumida de um/uma intelectual somente pode ser qualificada e justificada no instante do engajamento inventivo (Derrida 2004: 212-213). É nessa transação que aparece a possibilidade de suspensão. Essa operação pode levar à análise, à crítica, à desconstrução dos horizontes, dos critérios garantidos, das normas, das regras existentes. Essa inteligência presumida inventa ou propõe novas figuras (conceituais, normativas, criteriológicas) de acordo com novas singularidades, principalmente quando essas singularidades estão situadas em uma abertura para o olhar do outro, literalmente e materialmente na obra do outro. E falar do outro traz para bem próximo um "outro" [agora com aspas] muito caro a todo esse trabalho, já citado várias vezes ao longo do texto, mas que merece um olhar diferenciado neste momento: Jacques Derrida (1930-2004). Parece que nenhuma palavra consegue passar despercebida em sua escrita e na escrita dos outros que ele admira e respeita. Em seu arquivo de trabalho operatório, ele reflete sobre o papel do papel como metáfora de um tempo de vida (que ele menciona coincidir com o tempo de sua geração). Sobre a possibilidade do fim do uso do papel, poeticamente ele se refere aos escritos de Balzac. Ele se refere a um papel que se retira, reduz-se, retraise inexoravelmente à medida que um homem envelhece. Tudo o que passa a estar em jogo, então, é dispêndio e poupança, cálculo, velocidade, economia política. Como no romance de Balzac, trata-se de "saber", "saber" e "querer", com o acréscimo de uma nota de rodapé, que deve deixar neste momento de ser uma nota de rodapé, em uma tentativa de

(4) Derrida 2004: 158-162. Livre adaptação com comentários inseridos [uma bricolagem, em um sentido próximo da apropriação, conforme idéias de Michel de Certeau]. seguir o método de Derrida, quando ele acrescenta uma informação, ainda se referindo a Balzac: "Querer nos queima e Poder nos destrói; mas SABER deixa nossa fraca organização num perpétuo estado de calma". ${ }^{5}$

18. O que é que se escreve a partir da ação de cada sujeito? Se existe uma repressão no terreno das pesquisas ditas "científicas", ela talvez seja capaz de causar o efeito inconveniente de não perceber [ou não querer perceber] as práticas que lhes são heterogêneas. No entanto, não se deve ignorar que existe uma realidade fugidia e permanente - um paradoxo - um lugar e um não lugar onde se ativam, simultaneamente, forças estratégicas de poderes localizados e uma infinidade móbil de táticas. É nesse terreno móbil que aparece a "arte do fraco”. As táticas do colecionador podem utilizar as falhas das conjunturas particulares: ele tem que ser persistente, vigilante, caçador. Tem que saber o que quer e tem que conhecer o sistema local onde atua. $\mathrm{O}$ mesmo tipo de ação precisa ocorrer quando esse colecionador pretende dar um uso criativo para a posse de seus objetos. É assim que ele é capaz de criar a surpresa, pois ele joga com o terreno que lhe é imposto, movimentando-se dentro do campo de visão do "inimigo". Michel de Certeau observou que o poder se acha amarrado à sua própria visibilidade e que para lidar com essa visibilidade, o lado mais frágil tem que saber lidar com a dialética da estratégia e da tática. Desse modo, "sem lugar próprio, sem visão globalizante, cega e perspicaz como se fica no corpo a corpo sem distância, comandada pelos acasos do tempo, a tática é determinada pela ausência de poder, assim como a estratégia é organizada pelo postulado de um poder" (Certeau: 1994: 100-103).

19. O valor teórico de um discurso pode estar na astúcia de conhecer o saber científico e o poder que o funda. Se alguém se encontra na

(5) Derrida 2004: 217-218. A utilização das letras maiúsculas e em itálico na citação de Balzac segue a formatação original de Derrida. O romance em questão é La Peau de chagrin [A pele de onagro]. 
situação de fazer um discurso que esconde alguma coisa, o que está em jogo é uma situação de simulação ou talvez de dissimulação. Pode existir uma necessidade de se economizar o uso do local próprio, talvez para enfatizar as táticas e não as estratégias. Nesse caso, seria esperado que o valor teórico pudesse advir de uma explicitação das práticas daquilo que se sabe. É um paradoxo esconder aquilo que realmente sabe e, simultaneamente, explicitar as práticas daquilo que se sabe. $\mathrm{O}$ conhecimento verdadeiro ou a informação mais preciosa somente seria captado por alguém que também reconhece a astúcia do saber científico e sob quais poderes ele subsiste. O território estratégico pode estar no campo de uma ciência particular e precisaria evitar um confronto direto. Nesse caso, seria preciso agir como a arte, pois ela opera fora do discurso esclarecido e seus "observadores" se fazem colecionadores, descritores, analistas. Michel de Certeau se refere a Foucault e a Bourdieu como os "dois monumentos" que colocaram o campo de pesquisa em dois pólos opostos; no entanto, eles parecem ter utilizado um processo semelhante de fabricação de suas teorias: em primeiro lugar, destacam e, depois, colocam do lado avesso (invertem), ou seja, criam um isolamento "etnológico" e, em seguida, uma inversão lógica. A figura da modernidade estaria exatamente na exploração de uma realidade etnológica (Certeau 1994: 132-135). Uma coleção montada sob tais perspectivas evidenciaria também essa realidade etnológica.

20. A questão do equilíbrio entre dois pólos distintos revela uma "arte do tato". Tratase de uma faculdade de julgar que traduz um arranjo formal entre o imaginar e o compreender. O relato do tato deve ser visto como o discurso do homem comum ou ordinário, de qualquer pessoa. É o homem comum que se equilibra na corda bamba do cotidiano. Ele pode ter os seus segredos comuns guardados em uma pequena arca como coisas da infância de um saber. É esse sujeito que está situado, por questões óbvias de percepção e sobrevivência, em um lugar onde a prática precede o discurso teórico. Nesse campo, são as intuições e as astúcias que regem o nexo da relação entre o fazer e o conhecer. É esse sujeito ordinário que opera saberes que ainda estão fora do limite do discurso [principalmente o "discurso científico]. Na intuição e na astúcia do fazer estão histórias e /ou narrativas ocultas. A inteligência desse sujeito ordinário poderia oscilar entre os regimes do estético, do cognitivo ou do reflexivo. Nesse campo situado entre as práticas não discursivas da intuição e da astúcia pode ser localizada a arte de fazer. ${ }^{6}$

21. Uma coleção é como a costura de frases ou fragmentos de outros e que acaba se transformando em uma possibilidade de discurso. Não importa se as peças de uma coleção foram apropriadas como o resultado de uma escavação arqueológica, de uma pesquisa etnográfica ou mesmo adquiridas em uma relação de comércio. O que importa nesse momento é a posse, a apropriação envolvida nesse processo. Não existe um discurso puro, pois ele é efeito de uma rede de operações. O "efeito de plágio" é uma coisa moderna, um efeito de um discurso romântico idealista que criou o mito do autor original, do gênio ímpar (Bloom 1995). Harold Bloom, citando um ensaio de Burchfield, registra o uso da palavra plágio pela primeira vez em 1621 (e Burchfield menciona que a associação entre plágio, culpa e dissimulação surgiu bem mais tarde). Bloom também relata que toda a grande literatura é uma espécie de roubo, lembrando que Emerson afirmava, com satisfação, que "os Originais não eram originais" e que, por outro lado, Chaucer se apraz em atribuir crédito a autoridades fictícias (Bloom 2005: 187). Baudrillard também utilizou esse recurso ao atribuir ficticiamente uma citação sua como um versículo bíblico, em um ensaio sobre o simulacro. O discurso é um efeito de posse (ou um "discurso de posse"). A posse é uma convenção transitória. $\mathrm{O}$ máximo de posse é limitado pela existência, pela duração de um ser, enfim, a posse é uma coisa da vida e não da morte. Se a morte é o limite

(6) Fragmento redigido baseado na leitura de Certeau (1994: 146-149). 
do discurso, ela é também o limite da posse de algo. O discurso sempre diz algo do outro, sobre outro e para outro. Se existe alguma singularidade, ela está apenas no sujeito que "costurou", "organizou”, "colecionou”, "arquivou", enfim, no agente corpóreo e desejante [espinozista ou deleuziano?]. Pois é preciso uma vontade de desejo corporificada para que as coisas possam existir. Então, a lógica de uma coleção pode ser a de uma bricolagem, de uma construção em que as matérias-primas estão sempre relacionadas aos outros. A começar pelos nomes próprios. Uma coleção articula nomes em torno de práticas espaciais e práticas significantes. É a partir daí que se estrutura um discurso que leva a crer e autoriza um espaço de jogo. As obras criam legendas duplas: aquilo que se deve ler, assim como referência àquilo que se pode ler. As legendas têm um parentesco bem próximo com as lendas, com as invenções e com as relíquias.

22. A memória é o "antimuseu", ela não é localizável. O silêncio das coisas faz a memória falar dessas coisas ou dos outros colocados à distância, tirando da sombra os sonhos dos segredos. O relato da memória faz da ausência uma presença, transforma o discurso sobre as coisas em relíquias verbais. $\mathrm{O}$ capital da memória está em permanente alteração, ele nasce do outro [ou de circunstâncias do outro] simultaneamente perdendo-o. Ela vive de crer nos possiveis e de esperá-los, vigilante, à espreita. O discurso da memória leva a crer e depende das astúcias de um narrador. Esse discurso fala mais de uma ausência do que de uma presença, no entanto, ele está sempre autorizando um espaço de jogo. $\mathrm{O}$ jogo propõe uma memória das partidas, um repertório de histórias ou narrativas. $\mathrm{O}$ terreno aqui é o campo de operações da linguagem. Existe uma arte da memória assim como a arte do momento oportuno que produz a ocasião. A ocasião é o saber que tem por forma a duração de sua aquisição, a coleção de conhecimentos e escolhas particulares, heterogêneas, articuladas pela prática do tempo, o que acaba constituindo uma linguagem. A ocasião é como um princípio de economia que desaparece em seu próprio acontecimento, um mínimo de força para a obtenção máxima de um efeito (Certeau 1994: 56-157).

23. Uma coleção e a sua utilização propõem o estabelecimento de forças visíveis e invisíveis. A visibilidade torna-se óbvia pela própria materialidade ou existência física dos objetos, enquanto persiste como dado invisível da memória as escolhas das peças, suas histórias e trajetórias, as presenças e as ausências. Por sua vez, as ações pontuais (os usos, por exemplo) acarretam possibilidades de novos efeitos visíveis em uma dada ordem estabelecida. Michel de Certeau pergunta: qual a implantação da memória num lugar que já forma um conjunto? Este é o momento equilibrista e tático, o instante da arte. [...] A ocasião é "aproveitada", não criada. É fornecida pela conjuntura, isto é, por circunstâncias exteriores onde um bom golpe de vista consegue reconhecer o conjunto novo e favorável que irão constituir mediante um pormenor a mais. Um toque suplementar, e ficará "bom" (Certeau 1994: 160. 162). Sob esses aspectos "equilibristas e táticos”, as limitações, as tentativas mal sucedidas, as recusas, as impossibilidades, as portas fechadas podem criar situações mais favoráveis do que desfavoráveis nas mãos de um bom jogador.

24. Coleção como celebração de um enigma: o da visibilidade. Como entrar em posse de sua visão? Ela só aprende vendo, é desse modo que ela se apreende. Merleau-Ponty escreveu que "o olho vê o mundo e o que falta ao mundo para ser quadro, e o que falta ao quadro para ser ele próprio, e, na paleta, a cor que o quadro espera; e vê, uma vez feito, o quadro que responde a todas essas faltas, e vê os quadros dos outros, as respostas outras a outras faltas. (...) O olho é aquilo que foi sensibilizado por um certo impacto do mundo e o restitui ao visivel pelos traços da mão" (MerleauPonty 2004: 19-20). A citação pede para focar a atenção no que o olho vê e naquilo que ele não vê, ou seja, aquilo que ele sente falta no mundo para que o mundo seja um quadro. E aquilo que falta ao quadro para que ele tenha consciência de ser um quadro. É relevante a menção à paleta, às cores que o quadro espera como 
resposta para todas as ausências, pois essa esperança de resposta sustenta uma crença [uma fé perceptiva], afinal, como saber quais são as cores corretas que respondem a uma "ausência pressentida”? As cores ausentes que devem estar presentes como respostas somente podem estar situadas em um território imaginário, invisível. É necessário visualizar os quadros dos outros, o potencial de respostas outras para as mesmas questões de ausências e presenças. Uma coleção reúne esse conjunto potencial de respostas de olhares múltiplos que enxergaram o mundo e sentiram faltas, ausências daquilo que poderiam transformar o mundo em um quadro [metafórico ou não]. Se o olho é aquilo que foi sensibilizado por um impacto do mundo, o olhar de um colecionador está representado na reunião de olhares múltiplos dos outros que relatam uma multidão de ausências e presenças. A coleção se transforma em um único e novo quadro. Materialidades físicas experimentadas como uma coleção de impactos do mundo [ou de mundos?] que produzem um movimento potencial infinito e inesgotável de produção de outros impactos. Esse olhar, obviamente está possuído por um conceito de pintura, talvez uma "imagem", ou mesmo as pinturas ou imagens que possuem os conceitos. Essa posse quer se estender aos demais aspectos de um ser que, de todo modo, tenta se fazer visível.

25. Merleau-Ponty pergunta: "como nomear, onde colocar no mundo do entendimento essas operações ocultas, e os filtros, os idolos que elas preparam?" (Merleau-Ponty 2004: 23). Se o entendimento pretende se posicionar como algo que explicita uma operação, ele começa a operar pela nomeação das coisas. Entre os nomes e as coisas existirão sempre fronteiras invisíveis, talvez incompatíveis com os próprios nomes que tentam lhes atribuir. Os filtros são infinitos, pessoais, e ocultam mecanismos complexos que retêm algumas substâncias e deixam outras passarem. Os filtros podem ser colocados nos limites entre a visibilidade e a invisibilidade, entre os nomes e as coisas, entre as presenças e as ausências. Daí que o entendimento estará sempre intermediado por algum tipo de filtro que pode auxiliar ou distrair uma nomeação. Um tratado sobre o entendimento pressupõe a utilização de um método como um conhecimento reflexivo ou a idéia da idéia.

Todas as formas de conhecimento das "ciências humanas" podem ser questionadas exatamente por causa das operações ocultas e seus filtros. Quanto aos ídolos, não se sabe se Ponty se referia a Demócrito ou Bacon. Demócrito aponta para uma materialidade das imagens formadas por átomos emitidos pelos objetos e que afetam os órgãos dos sentidos, da alma ou o próprio pensamento. $\mathrm{O}$ que acontece com essa materialidade da imagem se os átomos passam por um determinado filtro? Os ídolos de Bacon ${ }^{7}$ têm em comum deficiências da linguagem, são ficções, imaginações, falsas representações profundamente enraizadas no espírito humano e impediriam o correto entendimento.

26. Pode-se transformar uma afirmação de Ponty em uma pergunta: "de que modo estamos entranhados no universal pelo que temos de mais pessoal (?)." (Merleau-Ponty 2004: 82 - adaptado). ${ }^{8}$ Um colecionador se transforma em um aliado ou cúmplice de todas as outras tentativas de expressão. Talvez, ele estaria tomado por uma grande tentação de acreditar que existe uma unidade do estilo humano, assim como haveria uma predisposição genética humana para a língua, se a teoria de uma linguagem universal de Chomsky estiver correta (Chomsky: 2005). A crença em uma unidade na variedade do estilo humano, fortemente influenciada por idéias de André Malraux, espera que essa unidade seja capaz de concentrar os gestos de todos os pintores (todos os artistas) em uma única tentativa. Todas as suas produções se

(7) Bacon classifica quatro ídolos que impedem seguir o verdadeiro caminho da ciência: ídolos da caverna, ídolos do teatro, ídolos da tribo e ídolos do mercado.

(8) Trecho original: "A pintura moderna coloca um problema muito diferente daquele da volta ao indivíduo: o problema de saber de que modo é possivel comunicar-se sem o amparo de uma Natureza preestabelecida e à qual se abriam os sentidos de todos nós, de que modo estamos entranhados no universal pelo que temos de mais pessoal.” Merleau-Ponty (2004: 82). 
resumiriam em uma única história cumulativa, em uma única arte. Essa aliança ou cumplicidade não deixaria de ser inscrita como apenas mais uma das tentativas, e, por isso mesmo, tal ambição não passaria de um indivíduo sucumbido por uma grande tentação. Tentação e ambição que estão no limiar de uma religiosidade, de uma poesia, de uma seita que constrói facilmente o seu universo segundo as perspectivas de um sonho ou da irracionalidade (Malraux 2000: 176). Paixões, tentações, movimentos, circunstâncias que denunciam um momento em que algo interno se faz externo. Uma emoção, sentimento, afecção que geram ações. A regra da ação, nesse caso, não é ser eficaz a qualquer preço, mas principalmente ser fecunda (Merleau-Ponty 2004: 106).

27. Diante das incertezas das tentações e paixões, a fecundidade da ação pode estar no campo da crença em uma transcendência. Se há sempre alguma coisa para dizer, também há sempre a vontade de significar. Existe um estranho envolvimento que faz com que a escolha dos meios já seja a escolha de um fim. "Aquilo que queremos dizer não está à nossa frente, fora de qualquer palavra, como uma pura significação. $\dot{E}$ apenas o excesso daquilo que vivemos sobre o que já foi dito" (Merleau-Ponty 2004: 118). O enigma da transfiguração: Deus se faz homem, "Ele desce dos céus", o verbo se faz carne e habita entre nós, o homem tenta se aproximar de Deus [ou o "ser demiurgo" de Platão, que contempla e produz], transformando-se em seu porta-voz ou em um portador privilegiado de sua obra. "O poder demiúrgico dos mestres do Irreal não é mais, para nós, do que um poder artístico" (Malraux 2000: 180). E o poder do conhecimento artístico é justamente o oposto daquilo que chamamos de um dom, pois o dom é uma coisa que logicamente tem de ser dada, se fosse adquirida não seria um dom (Danto 2005: 286). Daí que somente deve produzir uma obra, um artista ou uma consciência que esteja ciente que não tem consciência de tudo [não existe, nesse caso, "um dom genial"]. Alguém que está inquieto e está sempre procurando (talvez eternamente) ainda os vestígios daquilo de que ele ou ela não tem consciência. "Faz parte da estrutura de uma transfiguração metafórica que o objeto da metáfora mantenha sua identidade o tempo todo e seja reconhecido como tal" (Danto: 2005: 247).

28. Como exemplo mais clássico de colecionismo, o "Museu Imaginário" de André Malraux é um marco da consciência da pintura como pintura ou da arte como arte. Cada artista é visto como um agente que constitui uma linguagem única. Cada um está à procura de sua própria verdade e acaba acreditando que a maioria dos outros é uma "impostura". Malraux acreditava que somente havia fraternidade entre os pintores na morte (a mesma morte que limita o discurso, mas não é o seu fim). Apenas em um local livre das adversidades e lutas pessoais, no caso o espaço de um museu, é que todas as obras de tempos diversos poderiam ser olhadas como pertencentes a um mesmo universo. Desse modo, a fecundidade ilimitada de cada presente individual poderia estar justaposta sem os discursos de imposição e adversidades. Nesse ponto, esse museu que funda a consciência da arte como arte somente é visto ou percebido como uma consciência retrospectiva que depende de uma nova vida, uma forma nobre da memória. Apenas nesse espaço de memória nobre é que todas as pinturas (todas as artes ou objetos de relevância cultural) podem se juntar pelo que afirmam, independentemente da contradição, das adversidades ou das intenções dos autores e artistas [e dos colecionadores/coletores] que se opunham ou que se negavam em vida.

29. De que uma coleção está inevitavelmente privada? Em primeiro lugar, como todo museu, de tudo aquilo que não foi possível ser adquirido ou de tudo aquilo que não possui a devida "mobilidade". Malraux comenta que, mesmo envolvendo o emprego perseverante de meios imensos, o museu real, em oposição ao seu "Museu Imaginário", decorre de uma sucessão de felizes acasos. Esses acasos são legitimados pela razão de cada época (pois o museu transita entre o tempo). No entanto, essas razões múltiplas não deixam de se revelar como um mundo criado pelo e para o prazer da 
imaginação. Foi a partir do Romantismo que se operou uma transformação do "tesouro dos museus” por meio de metamorfoses, mutações, transfigurações de todos os valores. As aparições e ressurreições se transformam em espetáculos e surgem os ídolos, os gênios (alguns providencialmente malditos, pois todos os espetáculos precisam de protagonistas e antagonistas). O homem passa a ter valor pela sua faculdade de transmitir um mundo imaginado e criado por ele. Como uma "seita apaixonada", a arte torna-se um território em que a vida não é mais do que a matéria-prima. As coleções contribuem potencialmente para as ressurreições, pois são seleções entre muitas ofertas, uma oferta geralmente superior à demanda, pois é exatamente a partir do Romantismo que o artista passa a produzir para satisfazer a si próprio, em primeiro lugar, e deixa de atender a encomendas. São os colecionadores, com suas escolhas, que irão determinar quais obras merecem ser salvaguardadas, reunidas. $\mathrm{O}$ acaso oferece oportunidades, mas são os colecionadores que as escolhem. Se as coleções surgem com a mobilidade das obras, elas também, muitas vezes, se esquecem de seus locais privilegiados (castelos, igrejas, túmulos, sítios arqueológicos). Daquilo que é móvel para a moldura ou para a vitrina, até chegar ao museu, as coleções se transformam em locais intermediários. São antecâmaras do museu. $\mathrm{O}$ colecionador, segundo Malraux, sabe que é apenas um usufrutuário das obras que estão sob sua tutela, pois a coleção, como posse, tem uma relação estreita com o trânsito entre a vida e a morte. A posse é apenas uma instância do trânsito. Um estacionamento provisório.

\section{O "Museu Imaginário" de Malraux} propõe a tese de uma metamorfose do olhar e do sentimento diante das obras, principalmente aquelas classificadas como "arte". "O vasto departamento do Museu Imaginário que reúne os quadros e as estátuas, orienta a transformação dos verdadeiros museus por uma intelectualização sem precedente da arte, e pela sua destruição das pertenças"... (Malraux 2000: 216). As coleções, como domínios de imagens, refletem uma nova consciência de seus objetos. Por meio das imagens (e suas diversas técnicas reprodutivas) pode-se confrontar lado a lado a obra completa de um artista, a antologia de um estilo (ou a própria noção ambígua de "estilos"). São fatores para a consciência dessa nova imagem da obra de arte: o enquadramento; o detalhe; as cores [agora totalmente controláveis por processos digitais]; a questão bidimensional da fotografia [e o uso da fotografia em "preto e branco”, sugerido por Malraux, na época, 1965, em seu clássico ensaio]; a descontextualização dos formatos originais e redimensionamento de obras colocando-as praticamente em dimensões semelhantes. A reprodução fotográfica iguala tudo em imagens e o "modelo torna-se o meio da imagem, muito mais do que a imagem é a reprodução do modelo" (Malraux 2000: 88). "A reprodução não rivaliza com a obra-prima presente: evoca-a ou sugere-a. [...] Leva-nos a contemplar as obrasprimas que não são acessiveis, não a esquecê-las; $e$, sendo inacessiveis, que conheceríamos nós, sem a reprodução? Ora, a história da arte nos últimos cem anos, desde que escapa aos especialistas, é a história do que é fotografável" (idem, p. 108).

31. O ser humano alcança, cada vez mais, um estado de liberdade intelectual sem precedentes. Isso poderia vir a funcionar como um fator de impotência. Para Bergson, se um ser humano se contentasse em viver apenas, não haveria necessidade de outra coisa (Bergson 1999: 92). Mas isso não ocorre no universo, pois os seres humanos constituem verdadeiros "centros de indeterminação" (idem p. 34). Nesse processo de constituição indeterminada, transcender o ponto de vista particular é uma dificuldade que está presente tanto na conduta de vida como na reflexão. Somos seres muito complexos, estamos sempre em movimento, transitando entre pontos de vistas não unificados. Os impulsos ou pulsões de transcendência aliam forças destrutivas e construtivas. Uma nova relação com o mundo requer uma imersão naquilo que se quer compreender. Ao mesmo tempo, é necessário um recuo de uma visão inicial acerca desse mundo, caso contrário não se conseguirá vê-lo de uma perspectiva diferente. Supor que nós e a nossa aparência formamos parte de uma realidade mais ampla é 
a base para se justificar a busca do conhecimento mediante um afastamento proposital.

Também é preciso aceitar que nem toda a realidade será bem compreendida proporcionalmente ao aumento da objetividade em uma pesquisa. Seres em busca de um lugar. Talvez não seja possível definir qual é esse lugar que se procura tanto encontrar. Se "o caminho religioso pode parecer como o mais fácil e inquestionável desses lugares é porque, apesar (e depois de tudo), ele se mostra como a força ideológica mais poderosa que a história humana tem testemunhado" (Eagleton 2000/2005).

32. O universo existe apenas em pensamento ou fora dele? Partindo do corpo como o centro ao qual se relacionam todas as outras imagens não se pode ignorar que esse mesmo corpo tem a tendência a se mover [a se dispersar, talvez]. A confusão metafísica poderia ser vista como uma confusão psicológica (Bergson 1999: 48). Não resta dúvida que, tanto para os realistas como para os idealistas, a representação do universo material é relativa e subjetiva (idem, p. 55). Torna-se cada vez mais clara a noção de relativismo de um contexto quando se verifica que o presente sempre desloca o passado (ibidem, p.108). E isso pode estar relacionado com um ponto fundamental chamado "cérebro", local [ou órgão?] onde provavelmente [e a menção da palavra "provavelmente" é necessária exatamente por causa de todas as indeterminações e transitoriedades aqui tratadas] se faz o processamento, a análise e a seleção das percepções. Bergson chama o cérebro de "central telefônica", na falta ainda de modelos mais complexos, no entanto sem invalidar a metáfora [antes das noções de hardware x software]. É nessa "central telefônica" [que se pode ver como um dispositivo de hardware] que as percepções são processadas. De acordo com Bergson, "a percepção tem um interesse inteiramente especulativo; ela é conhecimen to puro. Toda a discussão tem por objeto a importância que é preciso atribuir a esse conhecimento em face do conhecimento científico. (...) Perceber significa antes de tudo conhecer" (Bergson 1999: 24). Ele reconhece que não há percepções que não estejam impregnadas de lembranças.
Bergson diz que "aos dados imediatos e presentes de nossos sentidos misturamos milhares de detalhes de nossa experiência passada" (idem, p.30). O território por excelência, ou o lugar [que não é exatamente um lugar] do processamento de todas essas informações é a memória. A conservação das imagens percebidas aconteceria exatamente nesse "fio contínuo da memória". A questão da literalidade da expressão "fio contínuo" não precisa ser analisada neste instante, a não ser que se pense o fio contínuo como o lugar da transmissão de uma corrente elétrica. Talvez a "corrente" fosse uma expressão metafórica mais adequada. E os impulsos elétricos, contínuos, descontínuos ou alternados? O importante é reter a impressão de que é a memória que permite a sobrevivência das imagens passadas, para que elas possam se tornar úteis e, a todo instante, completar a experiência presente com a experiência adquirida, e como essa não cessa de crescer, acabará por recobrir e fazer submergir a outra (idem $\mathrm{p}$. 69). De acordo com Bergson, ciência e consciência coincidiriam no instantâneo [no presente da "presença", no agora?].

33. A questão é saber como uma imagem é escolhida para fazer parte de uma percepção, enquanto uma infinidade de outras imagens permanece excluída (Bergson 1999: 40). Perceber conscientemente significa sempre estar a escolher (idem, p. 49) [ou "acolher"]. Não se consideram, neste instante, as percepções que não são conscientes ou que não são livres escolhas. No mundo das possibilidades de escolha humana, uma rede infinita de relações das escolhas conscientes [e inconscientes] dos outros determinam reflexos condicionais [ou condicionantes] nas opções de escolha disponíveis. No entanto, supondo que essa escolha implica em uma relação com o sujeito, existe um grau de afecção que determinada coisa exerce sobre alguém. $\mathrm{O}$ aumento gradual dessa percepção que pode vir a se concretizar em uma escolha também pode se transformar em dor. Bergson pergunta em qual momento e qual a razão especial "faz com que um fenômeno, de que eu era de início apenas o espectador indiferente, adquira de repente um interesse vital para mim?" 
(ibidem, p. 56). "Nossas sensações estão, portanto, para nossas percepções assim como a ação real de nosso corpo está para sua ação possível ou virtual. A ação virtual concerne aos outros objetos e se desenha nesses objetos; a ação real concerne ao próprio corpo e se desenha por conseqüência nele. Tudo se passará, enfim, como se [e o "como se", de Derrida, pode ser evocado aqui também], por um verdadeiro retorno das ações reais e virtuais a seus pontos de aplicação ou de origem, as imagens exteriores fossem refletidas por nosso corpo no espaço que o cerca, e as ações reais retidas por ele, no interior de sua substância. Eis por que sua superfície, limite comum do exterior e do interior, é a única porção da extensão que é ao mesmo tempo percebida e sentida. (...) Assim como os objetos exteriores são percebidos por mim onde se encontram, neles e não em mim, também meus estados afetivos são experimentados lá onde se produzem, isto é, num ponto determinado de meu corpo". (Bergson 1999: 58-59).

34. Ainda seguindo as pistas encontradas no território das idéias de Bergson, a subjetividade de nossa percepção consistiria, sobretudo, na contribuição de nossa memória. As qualidades sensíveis da matéria poderiam ser conhecidas em si, de dentro e não mais de fora, se pudéssemos separá-las desse ritmo particular de duração que caracteriza a consciência [o fio contínuo ou o encadeamento de elos de uma corrente]. Nesse ponto, Bergson conclui que as questões relativas ao sujeito e ao objeto, à sua distinção e à sua união, devem ser colocadas mais em função do tempo que do espaço (Bergson 1999: 75). Bergson, generosamente propõe uma solução para esse impasse entre subjetividade e materialidade. Ele diz que "haveria um meio, e apenas um, de refutar o materialismo: seria estabelecer que a matéria é absolutamente como ela parece ser. Por ai se eliminaria da matéria toda virtualidade, todo poder oculto, e os fenômenos do espirito teriam uma realidade independente" (idem, p. 77).

35. Seria possível associar o pensamento e a obra do artista Marcel Duchamp como uma tentativa de resposta para esse impasse? Bergson escreve que a memória é praticamente inseparável da percepção. Ela funciona intercalando o passado no presente, "condensa também, numa intuição única, momentos múltiplos da duração, e assim, por sua dupla operação, faz com que de fato percebamos a matéria em nós, enquanto de direito a percebemos nela" (Bergson 1999: 77). Percepção e memória: duas coisas entrelaçadas e completamente subjetivas que estão a nos oferecer situações complexas de escolha ou mesmo múltiplas possibilidades de atribuições de sentidos capitais para uma existência. "Daí a importância capital do problema da memória. Se a memória é o que se comunica sobretudo à percepção seu caráter subjetivo, eliminar sua contribuição, dizíamos, deverá ser o primeiro passo da filosofia da matéria" (idem). Para Bergson, a memória seria o palco de atuação do espírito e "a realidade de erigir o espirito em realidade independente se imporia" (idem p.78). Complexa realidade de um lugar que não é lugar, de um palco que remete a uma atuação, uma imaginação entre simulação e dissimulação capaz de pressupor a presença de um "espírito" atuando. Mas é preciso fazer descer esse "espírito" para um plano de uma "presença plena”. "Para evocar o passado em forma de imagem, é preciso poder abstrair-se da ação presente, é preciso saber dar valor ao inútil, é preciso querer sonhar. Talvez apenas o homem seja capaz de um esforço desse tipo" (ibidem p. 90). E não teria sido isso uma grande lição deixada pela obra e pensamento de Duchamp? Dar sentido ao inútil e ensinar que seria preciso querer sonhar? (vide Cabanne 2002). Não se pode ignorar que Duchamp tinha uma noção muito clara de que suas obras reais eram simplesmente imagens externas para se aproximar do [ou "rememorar" o] percurso de seu pensamento que remete a uma presença a si de uma linguagem. Sua obra/provocação "A Fonte" [de 1917] recebe um nome que não pode ser ignorado como algo que remete a um princípio, a uma origem. E não se pode esquecer que o pseudônimo utilizado pelo artista $[R$. Mutt] tem uma leitura sonora em inglês que lembra "are mute", ou "são mudos, sem som”, uma provocação para aqueles que dizem que "os objetos falam", principalmente os objetos de arte ou peças de uma coleção. Entre o som da palavra de uma presença viva e a representação simbólica desse som pode haver 
a menção do processo dos signos que aludem à presença de uma ausência [outro pseudônimo utilizado por Marcel Duchamp também fazia uso de trocadilhos sonoros; sua persona feminina Rrose Sélavy pode ser associada, entre outras interpretações, ao som da frase "Eros c'est la vie"; a repetição do " $\mathrm{r}$ " foi muito enfatizada por Duchamp]. Um pensamento estratégico de um jogador de xadrez interessado na memória de uma partida. Não é um acaso que ele mesmo produziu ou autorizou "reedições" [ou caixas com miniaturas] daquelas obras que ele considerava "as capitais" para se acompanhar o percurso de seu pensamento (vide Tomkins 2005). Se a memória tem um papel importante na constituição ou na eleição de focos de atenção, não se deve ignorar também que a brevidade da vida do ser humano impõe um "limite técnico" para a ação dessa memória enquanto uma "corrente contínua". No desenvolvimento do percurso humano, houve a necessidade da criação de métodos ou fórmulas externas de acumulação ou impregnação [ou impressão] de vivências anteriores em coisas [suportes físicos] com duração externa à própria memória [o pensamento do rastro]. Arquivos de memórias, dos fios ou elos de correntes que se transformam em registros, fragmentos, traços, inscrições e impressões que necessitam durar, salvar-se da destruição. São coisas que podem ser transmitidas às gerações do porvir. Caso contrário, o homem estaria sempre destinado a refazer todo o percurso de experiências e descobertas da existência de sua própria espécie (o "homo sapiens") sempre retornando à caverna e sua vida pré-sedentária, pré-agricultura ["pré-pá-lavra”].

36. Desaparece um colecionador de idéias que acharia divertido conservar o acaso: Duchamp faleceu em 1968. No mesmo ano, Baudrillard publicou o seu "Sistema dos Objetos". ${ }^{9}$ Sua proposição era saber como os objetos são vividos, a que necessidades, além

(9) Título original: Le système des objets. Paris: Éditions Gallimard, 1968. Os trechos em itálico correspondem às citações da tradução brasileira: Baudrillard 1993. das funcionais, eles atendem. Quais as estruturas mentais que se misturam às estruturas funcionais e as contradizem, sobre que sistema cultural, infra ou transcultural, é fundada a sua cotidianidade vivida (Baudrillard 1993: 10). Os objetos são por natureza antropomórficos e conduzem um discurso segundo uma multiplicidade de combinações ilimitadas. $\mathrm{O}$ homem, nesse sistema, seria o homem do arranjo, o ser de uma relação e de uma ambiência: um homem funcional. No jogo dos objetos existe a mobilização de um espaço como uma mensagem para os outros e para si próprio. A imagem seria o contrário do objeto, pois ela omite sua presença. Dentro desse sistema, o signo do objeto é o tempo, não o tempo real, mas uma presença alegórica do tempo mitológico. O objeto de coleção é vivido de outra maneira quando, não servindo para nada, serve profundamente para qualquer coisa, ele ocorre no presente como se tivesse ocorrido no passado e, por isso mesmo acha-se fundado sobre si, "autêntico" (idem, p.83). Existe aqui uma nostalgia das origens e a obsessão pela autenticidade [a saudade da raridade, tão cara ao artista Marcel Duchamp?].

37. O objeto de coleção tem a obsessão da origem da obra, de sua data, de seu autor, de sua assinatura. "Ora, a procura do traço criador, da marca real à assinatura, é também a da filiação e da transcendência paterna. A autenticidade vem sempre do Pai: [nitidamente uma leitura freudiana ou lembrando a origem do termo "patrimônio"] é ela [a autenticidade] a fonte do valor. E é esta filiação sublime que o objeto antigo [ou objeto de coleção] suscita à imaginação ao mesmo tempo que a involução para o seio da mãe" (Baudrillard 1993: 85). O valor adquirido é um valor hereditário, está relacionado com uma "graça recebida" e depositada simbolicamente em signos materiais para um porvir de transcendência. São objetos amados, alvos de uma relação de paixão [uma febre ou um mal de arquivo] "cujo investimento afetivo não fica atrás em nada àquele das paixões humanas, paixão cotidiana que freqüentemente prevalece sobre todas as outras, que por vezes reina sozinha na ausência das outras" (idem, p.93). O ser humano, nesse sistema, reorganiza os 
objetos de coleção de um "modo constelado" [deve-se reter essa informação de uma reorganização de objetos de coleção de um "modo constelado"], "oposto à organização funcional em extensão, e visando preservá-lo desta irrealidade profunda, essencial sem dúvida, do foro intimo. Símbolo do esquema de inscrição do valor num círculo fechado e num tempo perfeito, o objeto mitológico não é mais um discurso para os outros, mas para si mesmo" (ibidem, p.88).

38. Em uma coleção, todos os objetos se equivalem na relação de posse, uma abstração apaixonada em que um apenas não é o suficiente. Trata-se de um jogo de sucessões em que existe a procura, assim como o agrupamento e a ordenação. A posse mistura-se ao uso e é abstraída de sua função e totalmente relacionada ao indivíduo. Se ela é relacionada totalmente ao colecionador, talvez não seja absurdo afirmar que ele está colecionando [ou tomando posse de] fragmentos dispersos de si mesmo. Tais objetos "constituem-se, pois em sistema graças ao qual o indivíduo tenta reconstituir um mundo, uma totalidade privada" (Baudrillard 1993: 94). Se existe uma astúcia envolvida, trata-se da "astúcia da subjetividade: o objeto possuido jamais é uma mediação pobre. Sempre é uma singularidade absoluta" (idem, p.98).

39. A organização de uma coleção está em sincronia direta com uma relação temporal. O colecionador está sempre "inventariando o tempo em termos fixos com os quais pode jogar reversivelmente, a coleção representa o perpétuo reinício de um ciclo dirigido onde o homem se entrega a cada instante e com absoluta segurança - partindo não importa de que termo e seguro de a ele voltar - ao jogo do nascimento e da morte" (Baudrillard 1993: 103).

40. Poderia ser preciso provar alguma coisa em um texto, em uma inscrição, em uma escritura. Existiriam evidências para comprovar tudo aquilo que já foi escrito? Poderia haver um paradoxo entre as evidências materiais e tudo aquilo que está nas escrituras. Entre o início e o fim de algo, muitas outras coisas poderiam se insinuar. Talvez até uma traição. Alguém poderia omitir, intencionalmente ou não, o assunto principal do qual tudo parecia provir. Por mais que se tentasse escapar e exercer controle, mais cedo ou mais tarde a contradição sempre seria revelada. Sempre foi assim. Ela mesma, a contradição, poderia ser um ponto sensivel a ser abordado. Mas a contradição abordada intencionalmente não seria mais uma negação de alguma coisa, seria uma afirmação. Não importa qual a decisão e qual o caminho que se optasse seguir, haveria sempre um ponto cego que não permitiria que se enxergasse em determinados espaços. Qual investigação revelaria esse ponto sensivel e obscuro? Ele estaria em um átomo ou em seu núcleo? Seria uma partícula indivisível? Onde ele se revelaria? Mas esse algo inexprimível, esse dado paradoxal que escapa ao controle da intenção, não seria ele a real contribuição de um texto? Talvez esse ponto tivesse uma vontade própria e ele poderia se insinuar por si próprio. O que o sujeito deveria fazer nesse caso? Agir como um médium e deixar o tempo fazer o seu próprio trabalho, como sugeriu Duchamp? Talvez essa mediunidade textual seja a verdadeira e única contribuição de um autor, a razão de sua própria existência. $\mathrm{O}$ post scriptum.

41. Esse ponto minúsculo poderia ser um centro ou mesmo uma ausência de centro. Ele justificaria toda a pesquisa empreendida, todo o esforço gasto, todo o papel impresso, todos os livros lidos, todos os objetos colecionados, todos os documentos arquivados, todas as evidências de prova, todo o raciocínio aplicado e todas as coisas que foram destruídas nesse processo pelo esquecimento, pelas falhas da memória, pelos lapsos e erros de crença e imaginação. Poderia existir tal ponto? Se ele existisse e fosse da ordem do inexprimível, do intangivel, ele também se revelaria como sendo da ordem do improvável, do inevidenciável. Mas ele também seria inevitável. Tal coisa poderia se desprender da existência de um sujeito? Ela poderia prescindir de uma ação subjetiva para deixá-la fluir? Se por uma absurda hipótese esse ponto fosse dito (ou escrito) em apenas uma única frase, imediatamente, alguém seria capaz de acreditar nele? Ou entraríamos nos domínios da fé? Obvia- 
mente, um leitor poderia levantar a hipótese de que tal ponto foi uma invenção qualquer de uma imaginação capaz de utilizá-lo como um simples pretexto para ocupar algumas páginas e satisfazer um sistema que não é mais capaz de prescindir de um discurso muito complexo. E para quê serviria tudo isso, toda essa complexidade? Se existe aqui um problema na linguagem, talvez também seja porque exista uma situação semelhante da linguagem. Algo se esconde "na [da]" própria linguagem (Baudrillard 2007; Braga 2008).

42. Qual a finalidade dessa investigação? Entre o dizer, escrever ou acreditar, qual o propósito desse exercício? Não haveria uma grande responsabilidade ao se exercer um grau de autoridade que representa um sistema de poder? Haveria alguma possibilidade de não ter que exercer esse poder? Ele é realmente imprescindivel? Todas as páginas preenchidas de um discurso de um sujeito qualquer poderiam acrescentar algo mais aos bilhões ou trilhões de páginas já escritas e arquivadas? Toda essa escritura teria alguma finalidade além daquela prescrita por uma instância de juízo? Duchamp não queria ter responsabilidade alguma, ele disse. Pilatos lavou suas mãos, está escrito. Alguém poderia ser levado a crer na hipótese de que aquele ponto sensível seria capaz de transmitir a si próprio "através" de todo um discurso. Se isso ocorresse, todo o esforço teria valido a pena, mesmo que esse alguém não tivesse percebido aquilo que estivesse tentando escrever, ele acreditaria.

43. Se nós partirmos da análise de um determinado contexto, inevitavelmente percorreremos um terreno traspassado por pretextos alheios. Algo que está explícito literalmente nessas palavras anteriores e no próprio percurso traçado é exatamente a existência de um texto. Se em um contexto pode-se analisar pontos sensíveis de encontro de pretextos diversos, em algum momento, torna-se necessário refletir sobre o processo que possibilitou a própria transcrição dessas idéias organizadas em forma de textos. Esses textos, por maior que seja a tentativa exercitada de serem objetivos, falam também da impossibilidade de atingir essa objetividade por causa de uma limitação óbvia: eles são redigidos por alguém que enfrenta, reproduz, expõe, nega ou oculta todos os reflexos de contextos e pretextos que os antecederam. O ser humano nasce em um mundo com toda uma estrutura [e infraestrutura] já preparada para receber novos seres. Ele tem que ser capaz de aprender a lidar com tudo aquilo que o precedeu, manejar todos os instrumentos que já existiam muito antes de ele nascer, considerando aqui, como instrumentos, não apenas os sistemas de uma natureza física pré-existente, assim como os dispositivos que poderíamos comparar com o hardware, mas principalmente as questões relacionadas com o software. O tempo de validade ou duração desses softwares é cada vez menor ou mais acelerado. Para isso, o ser humano precisa, cada vez mais, aprender a acelerar o uso de duas faculdades próprias de sua capacidade ontológica: crer e inventar.

44. Em alguns pontos, tem-se a capacidade de compartilhar experiências similares ou opostas transmitidas pela utilização de caracteres que pressupõe acordos prévios que envolvem crenças e invenções. Essa capacidade foi construída sobre uma base completamente artificial, totalmente inventada [talvez após uma grande catástrofe, teria escrito Derrida]. E foi preciso alguém crer nesse sistema artificial e aprender a manejá-lo de acordo também com regras que não passam de acordos de crença e invenção. Existem as crenças e invenções verdadeiras e todas aquelas outras que nos são impostas. Mas como distinguir umas das outras? Como ter parâmetros? É preciso supor uma base comum para amparar uma ética da discussão ou para a questão da Verdade, como salienta a "mudança de paradigma" proposto por Jürgen Habermas (Habermas 2004). Essa mudança de paradigma é o sujeito ter a capacidade de assumir o ponto de vista oposto, o ponto de vista em confronto ou conflito com as suas próprias crenças. De acordo com esse filósofo, "quando tomamos consciência de que a história e a cultura são fontes de uma imensa variedade de formas simbólicas, bem como da 
especificidade das identidades individuais e coletivas, percebemos também, pelo mesmo ato, o tamanho do desafio representado pelo pluralismo epistêmico" (Habermas 2004: 9).

45. Habermas está interessado em discutir qual a prática que poderia atender igualmente aos interesses de todos. Ele diz que "é evidente que a autoconsciência e a capacidade da pessoa de assumir uma posição refletida e deliberada quanto às próprias crenças, desejos, valores e princípios, mesmo quanto ao projeto de toda a sua vida, é um dos requisitos necessários para o discurso prático. Há um outro requisito, porém, tão importante quanto esse. Os participantes, no momento mesmo em que encetam uma tal prática argumentativa, têm de estar dispostos a atender à exigência de cooperar uns com os outros na busca de razóes aceitáveis para os outros; e, mais ainda, têm de estar dispostos a deixarse afetar e motivar, em suas decisões afirmativas e negativas, por essas razões e somente por elas" (Habermas 2004: 15). É nesse sentido que um sujeito poderia abrir mão de sua preferência momentânea, de uma vontade própria de fazer outra coisa, "compor música", por exemplo. No entanto, redigir um texto pode se transformar em um dos requisitos necessários para exercer outro tipo de discurso prático e atender a uma exigência de cooperar uns com os outros na busca de razões comuns aceitáveis para os outros e seus pretextos existenciais.

46. O conhecimento, de acordo com Habermas, "resulta de três processos simultâneos, que se corrigem entre si: a atitude de resolver problemas diante dos riscos impostos por um ambiente complexo, a justificação das alegações de validade diante de argumentos opostos e um aprendizado cumulativo que depende do reexame dos próprios erros." (Habermas 2004: 57). A possibilidade de existência de pretextos, textos e contextos diversos surge a partir do exercício do compartilhamento das linguagens que inventamos sob os mais diversos pontos de vista. Ainda de acordo com Habermas, "dependendo das linguagens teóricas que escolhemos, pode haver descrições diferentes - capazes de se referir, porém, às mesmas coisas. Assim, o mundo não deve ser concebido como a totalidade dos fatos dependen- tes da linguagem, mas como a totalidade dos objetos." (Habermas 2004: 58). Os objetos, aquí, novamente, são pontos referenciais para a concepção de um discurso "de mundo".

47. Na prática cotidiana, são as crenças que "desempenham diferentes papéis e têm sua verdade provada de diferentes maneiras na ação e no discurso" (Habermas 2004: 58). Habermas diz que é em nosso mundo vital, que os agentes dependem das certezas e reagem às surpresas e decepções. Eles têm que lidar com um mundo que "presumem ser objetivo, e, em virtude desse pressuposto, operam segundo uma distinção de senso comum entre o conhecimento e a opinião - entre o que é a verdade e o que só parece sếlo. No decurso de nossa rotina cotidiana, temos a necessidade prática de confiar intuitivamente naquilo que consideramos incondicionalmente verdadeiro" (idem, p.61-62). O que se entende aqui é que as crenças não deveriam ser substituídas por certezas, talvez o efeito desejável fosse exatamente o oposto: as crenças deveriam pressupor dúvidas. Somente por meio da dúvida é que poderíamos nos colocar no ponto de vista do outro e supor que poderiam existir crenças diferentes das nossas. Para Vilém Flusser, a dúvida é polivalente, significando mesmo o fim e a procura de uma certeza, além de, se levada ao extremo, conduzir ao ceticismo, que seria uma "certeza invertida". Em doses excessivas, ela paralisaria o intelecto, mas como experiência intelectual seria um dos "prazeres puros". Como "experiência moral" seria uma tortura e como aceitação ingênua dos dados poderia ser vista como um dos pontos de partida para a "fé" (Flusser 2002:47).

48. Quanto às questões da crença e da invenção, Gilles Deleuze esclarece que, "crer é inferir de uma parte da natureza uma outra parte que não está dada. E inventar é distinguir poderes, é constituir totalidades funcionais, totalidades que tampouco estão dadas na natureza" (Deleuze 2001: 94). Portanto, a dúvida é uma das condições que estão presentes na crença (embora a maioria das pessoas não cogite nessa situação). Para crer é necessário ter a consciência de que esse processo de inferir algo ou alguma coisa vem da pressuposição de que 
existe outra parte, outro algo, outras coisas que não estão dadas. Se a invenção trabalha exatamente com a distinção de poderes, com a constituição de totalidades funcionais que também não estão dadas na natureza, convém estar atento que aí também existe uma brecha para que haja a existência da dúvida e se afaste o perigo imenso da certeza. Para a constituição de um texto, torna-se imprescindivel uma compreensão aprofundada dessas duas palavras, pois é na crença e na invenção que muitos dados são estabelecidos. Independentemente da necessidade de uma fé transcendente, no sentido religioso, seria necessário um acordo de que é na crença e na invenção que residem as origens [gêneses, genealogias, gêneros] das coisas que estabelecem novos pretextos e contextos de ação [e reação]. Percebe-se, portanto, que existe uma responsabilidade nesses processos envolvendo as crenças e as invenções. A responsabilidade é o estabelecimento de uma capacidade de consciência ou discernimento de que nos processos cognitivos que envolvem crenças e invenções, deve-se distinguir que a dúvida é o melhor caminho para evitar as confusões frequentes envolvendo as duas palavras: fé e certeza. Pois é no momento contemporâneo ao exercício dessas duas faculdades que se estabelecem novos parâmetros e paradigmas para as gerações vindouras. Então, é inevitável a necessidade da conscientização do envolvimento do fator de responsabilidade para todos aqueles que exercem suas capacidades de crença e de invenção. Pois ao atuarem ou agirem, estarão no comando de criação de novos mecanismos que operam ciclicamente em contextos e pretextos com possibilidades de reações irreversíveis em cadeia. O efeito dessas reações não deve ser subestimado diante da possibilidade e predisposição irônica do ser humano.

49. De acordo com Deleuze, o "sujeito que inventa e crê se constitui no dado de tal maneira que ele faz do próprio dado uma sintese, um sistema." (Deleuze 2001: 94-95) Importante notar nessa observação que é o próprio sujeito (que inventa e crê) que tem a capacidade também de se constituir no dado em si, fazendo de si próprio uma possibilidade de síntese ou algo muito mais complexo como um sistema. Então, quer seja a síntese ou quer seja o sistema, ambos são resultados de um exercício de crença e invenção de sujeitos cujos propósitos estão submetidos a toda probabilidade, à variabilidade e complexidade de relações com os outros sujeitos (que também estão na mesma posição de crer e inventar). Se os sujeitos são muitos, as probabilidades de variação dos propósitos de crença e invenção são infinitas. Possibilidades infinitas de aberturas. Também são muitos os acordos necessários para estabelecer pontos comuns de diálogos e convergências de interesses. A filosofia entra como base para amparar as possibilidades de discussão desses acordos que envolvem crenças e invenções. Deleuze mesmo explicita essa posição ao dizer que "a filosofia em geral sempre procurou um plano de análise, de onde pudesse empreender e conduzir o exame das estruturas da consciência, isto é, a critica, e justificar o todo da experiência." (idem, p. 94-95).

50. A existência de uma crítica e uma justificação de um todo da experiência propõe mais uma questão: "como pode haver o dado, como pode algo dar-se a um sujeito, como pode o sujeito dar a si algo?" (...) "como se constitui ele no dado? A construção do dado cede lugar à constituição do sujeito. O dado já não é dado a um sujeito; este se constitui no dado" (Deleuze 2001: 94-95). Assim, Deleuze, trabalhando em um ensaio sobre a natureza humana, de acordo com Hume, revela que a menor idéia, a menor impressão não é um ponto matemático, nem um ponto físico, mas simplesmente "um ponto sensível". Esse ponto sensível está relacionado com a existência de uma subjetividade. Simultaneamente, esse ponto sensível "propõe uma extensão de espaço na disposição dos objetos visiveis e tangíveis, assim como descobre o tempo na sucessão perceptivel dos objetos cambiantes" (idem, p. 100-101). Importante notar a inclusão de uma extensão de espaço e de tempo nessa sucessão perceptível dos objetos. Se isso, por um lado, complica a aplicação de uma tentativa de localização desse ponto sensível, por outro lado, facilita a compreensão empírica da complexidade do assunto em questão. 
51. Para Deleuze, o dado não está no espaço, o espaço é que está no dado, e ele vai muito além, o espaço e o tempo estão no espírito. Espírito de quem? Onde está esse espírito? Quem é ele? As principais características do sujeito são ressaltadas exatamente na crença e na invenção e agora já se pode falar até em um espírito. Entretanto, neste texto não se pretende abordar assuntos religiosos e muito menos entrar na discussão sobre o "ser e o espírito", como a questão de Heidegger (Derrida 1990); deve-se ater a uma tentativa de se respeitar o corte proposto. ${ }^{10} \mathrm{Em}$ determinadas situações, deve-se apropriar de uma linguagem de outros campos, talvez a referência à Metafísica seja inevitável. Mas o espírito em questão seja artificial ou humano, mais para "demasiadamente humano", talvez esteja sobre o chão como qualquer outra coisa.

52. Como conservar ou arquivar um "arquivo-de-si" para si mesmo? Haveria essa possibilidade? Para Deleuze: "crer é esperar" [a duração supõe uma espera]. "Comunicar a uma idéia a vivacidade da impressão a que ela está ligada [existe um processo de comunicação em jogo que supõe uma conexão entre uma idéia e uma impressão] é esperar, é ultrapassar a memória e os sentidos. Para isso ainda é preciso que haja relações entre as idéias, é preciso, por exemplo, que o calor esteja unido ao fogo; isso não implica apenas o dado, mas a ação de princípios, a experiência como um princípio, a semelhança e a contigüidade. E isso não é tudo; é preciso que, vendo de longe o fogo, acreditemos no calor, o que implica o hábito" (Deleuze 2001: 150-151). "E o sujeito não só espera, como também se conserva a si mesmo; isso quer dizer que ele reage à totalidade das partes do dado seja por instinto, seja por invenção". (...) "Em suma, crendo e inventando, fazemos do próprio dado uma Natureza. Eis ai onde a filosofia de Hume encontra seu ponto último: essa Natureza é conforme ao Ser [toma a forma do Ser?]; a natureza humana é conforme à Natureza, mas em que sentido? No dado, estabelece-

(10) Deleuze discute a questão de como conceber um corte em uma formação discursiva. "Há sempre um momento, ou locais, em que as séries começam a divergir e se distribuem em um novo espaço: é por onde passa o corte". Deleuze (1988: 31). mos as relações, formamos totalidades. Estas não dependem do dado, mas de princípios que conhecemos; são puramente funcionais" (idem). O sujeito precisa aprender a agir com essas relações, com essas totalidades. É assim que ele pode se propor conservar como um "arquivo-de-si" em um sistema de crença e invenção que tem a forma da natureza humana que está conformada a uma Natureza.

53. Para haver propriedade, trata-se aqui de posse material das coisas, foi preciso haver um acordo entre sujeitos e o estabelecimento de algumas regras gerais. Tais acordos parecem surgir a partir de uma tendência sedentária humana. O endereço fixo ao invés do nomadismo determinou uma série de acordos necessários para se manter e prolongar a posse sobre as coisas e lugares. Hume (apud Deleuze 2001: 103) diz que "há vários estados de posse, determinados por relações complexas: posse atual, antes da instituição da sociedade; e, uma vez instituída a sociedade, ocupação, prescrição, acessão, sucessão". No entanto, Hume continua, "é no dinamismo do hábito e da expectativa que faz desses estados direitos à propriedade". Além de conservar a si mesmo, de acordo com Hume, "cada homem espera conservar o que possui” (idem, p. 103). Para Deleuze, "é evidente que as relações não têm por causas as propriedades das próprias idéias entre as quais elas se estabelecem. Se elas têm outras causas, então essas outras causas determinam um sujeito, que é o único a estabelecer as relações em uma coleção de idéias" (idem, p. 110-111). No entanto, esse sujeito único é finito e tem uma duração determinada. Se ele pretende que a sua coleção de idéias determinantes [ele crê que essas idéias possam conservar a si mesmo além de sua própria duração] é preciso a invenção de acordos complexos que cumpram essas expectativas.

54. Deleuze cita Hume: "a circunstância está no centro da história, torna possivel uma ciência do particular, uma psicologia diferencial". Conhecer a circunstância em que se age é fundamental para qualquer exercício de autoridade [ou autoria]. A circunstância envolve toda a complexidade de acordos necessários e determinantes nas relações entre posse e propriedade de coisas e idéias 
[bens e direitos]. De acordo com Deleuze, o que dá à relação sua razão suficiente é a circunstância e as circunstâncias estão permeadas de afetividades: paixões e necessidades, "uma repartição de seus interesses, uma distribuição de suas crenças e de suas vivacidades" (Deleuze 2001: 116). Portanto, se a razão suficiente para a existência de crença e invenção está nas circunstâncias, não se pode ignorar que essas circunstâncias estão repletas de situações envolvendo relações de afecções. E a afetividade [tanto as paixões quanto as necessidades] não deixa de escapar dos sujeitos aos quais ela "afeta". O que pode ser paixão (ou aversão) para uns, pode ser uma absoluta necessidade para outros e vice-versa. Deleuze conclui seu estudo sobre Hume com a observação de que "a filosofia deve se constituir como a teoria do que fazemos, não como a teoria do que é. O que fazemos tem seus princípios; e o Ser só pode ser apreendido como objeto de uma relação sintética com os próprios principios daquilo que fazemos".(idem, p. 151).

55. Foucault deixou claro que em todo discurso explícito havia também um discurso oculto. Cada frase se ampliaria com tudo aquilo que ela própria não seria capaz de dizer. Uma dialética das frases, portanto, estaria sempre submetida à contradição, mesmo que apenas para superá-la ou aprofundá-la (Foucault 1979; 1989). Deleuze, profundo admirador da obra de Foucault, concordava que a contradição e a abstração são processos de proliferação de frases e das proposições, tal como a possibilidade de opor sempre uma frase a outra frase, ou de formular mais uma proposição sobre outra proposição (Foucault apud Deleuze 1988: 14-15).

56. Foucault apontou que os enunciados são, essencialmente, raros. No entanto, apesar da raridade, não haveria nenhuma necessidade de ser original para produzi-los. Um enunciado, nesse caso, representaria sempre uma emissão de singularidades, de pontos singulares que se distribuem num espaço correspondente (Deleuze 1988: 14-15). Então, nosso ponto sensível não precisa mais ser original, único e exclusivo. Se a originalidade não é mais uma questão pertinente, no entanto, o enunciado deveria ser o objeto específico de um acúmulo por meio do qual ele poderia se conservar, transmitir-se ou até mesmo se repetir. Deleuze diz que "o acúmulo é como a constituição de um estoque, não é o contrário da raridade, mas efeito dessa mesma raridade. Por isso, substitui as noções de origem, e de retorno à origem: tal como a memória bergsoniana, o enunciado se conserva em si, em seu espaço, e vive enquanto esse espaço durar ou for reconstituido" (idem, p. 16; para a questão "bergsoniana" vide Deleuze 1999). Fica mais claro que esse ponto sensível, apesar de não precisar ser original, se transformaria em algo raro exatamente por ser um acúmulo único de enunciados. Seria na constituição desse acúmulo ou estoque, que ele passaria a se constituir em um efeito dessa raridade sonhada. Resta saber se seria possível reconhecer esse acúmulo de enunciados que constituiria alguma coisa (ou alguma representação) como um "efeito de uma raridade".

57. A circunstância única e exclusiva estaria exatamente nas possibilidades raras (não necessariamente originais) de entrecruzamentos e acumulações de estoques desses enunciados em um sujeito variável. "A relação entre o enunciado e um sujeito variável constitui ela mesma uma variável intrínseca do enunciado" (Deleuze 1988: 18). Não podemos e nem devemos esquecer a identidade dinâmica dos sujeitos e que por isso mesmo, os fatores de variabilidade e possibilidades de construção de discursos também seriam infinitos. Se o referente ou o intencional é uma das condições intrínsecas dos objetos e conceitos dos enunciados, o estado de coisas, derivado do próprio enunciado define uma variável extrinseca que se constitui em um objeto discursivo (idem, p. 19). É esse objeto discursivo que pode ser conservado como uma referência à intenção de um sujeito. Esse discurso demarca o espaço de uma singularidade [uma raridade] em uma série de variabilidades. Em seu estudo sobre Foucault, Deleuze escreve que os enunciados se distinguem das palavras, frases e proposições "porque eles englobam, como seus derivados, tanto as funções de sujeito como as de objeto e de conceito. (...) Assim, o espaço correlativo 
é a ordem discursiva dos lugares ou posições dos sujeitos, dos objetos e dos conceitos numa família de enunciados" (ibidem, p. 20-21). Para Foucault, uma instituição também comportaria alguns enunciados. Ele cita como exemplos: uma constituição, uma carta, contrato, inscrições e registros. Inversamente, os enunciados remetem a um meio institucional sem o qual os objetos surgidos nesses lugares do enunciado não poderiam ser formados, nem o sujeito que fala de tal lugar (por exemplo, a posição do escritor numa sociedade, a posição do médico no hospital ou em seu consultório, em determinada época, e o surgimento de novos objetos) (ibidem, p. 21). Assim, o reconhecimento da posição de titularidade [a autoridade] de um "autor" somente é comportado em um enunciado se o seu espaço correlativo supõe uma aceitação da ordem discursiva entre as disposições dos lugares dos sujeitos, seus objetos, conceitos englobados por acordos institucionais.

58. Pode-se fazer uma proposição de constituir uma coleção de objetos como um conjunto de enunciados que remetem a uma fatia de espaço extrínseca ao sujeito. Trata-se de uma coleção de formações discursivas assumindo todas as suas multiplicidades (por exemplo: época, autores, contextos, formações históricas etc.). Se a coleção pode ser vista como um conjunto de enunciados, não se pode ignorar que esses enunciados cujas funções poderiam ser consideradas primitivas, também seriam totalmente anônimos se não houvesse um sujeito frásico ou dialético, a primeira pessoa com a qual se inicia (ou se iniciou) um discurso. Existe um sentido manifesto e isso implica, obviamente, em algo não manifesto. Ao enunciado, "a um só tempo, não é visivel e não é oculto", Deleuze acrescenta que "toda sobrescrição, toda subscrição remetem à inscrição única do enunciado em sua formação discursiva: monumento de arquivo, e não documento" (Deleuze 1988: 27).

59. Existe alguma diferença entre um monumento de arquivo e um documento? Pode-se considerar um monumento de arquivo como a definição de algo com a finalidade de transmitir à posteridade, salvaguardar a memó- ria de um fato ou de um sujeito, incluindo a função de "arquivo-de-si-próprio". O documento serve exatamente como um título, um contrato, um certificado, um diploma [uma representação de um acordo institucionall para comprovar ou provar alguma coisa ou fato circunstancial. Existe um ponto em que as definições podem se tornar mais complexas e um monumento de arquivo poderia englobar objetos que incluem uma série de documentos comprobatórios de situações diversas que poderiam ser questionadas [as pesquisas ditas "científicas" se encaixariam nesse caso]. Esses documentos evidenciariam conceitos e idéias que relacionam o sujeito às circunstâncias que ele se propõe arquivar. No entanto, existe a hipótese de que tais evidências poderiam ser consideradas desnecessárias se as condições prévias para sua existência já estavam contidas nas próprias interpretações e formulações anteriores ao discurso. Foucault esclarece que as palavras, frases e proposições retidas no corpus devem ser escolhidas em torno dos focos difusos de poder (e de resistência) acionados por esse ou aquele problema. Desse modo, a linguagem poderia ser utilizada como um meio de distribuição ou de dispersão de enunciados. Deleuze deixa claro que "os enunciados de Foucault não são palauras, frases ou proposições, mas formações que apenas se destacam de seus corpus quando os sujeitos da frase, os objetos da proposição, os significados das palavras mudam de natureza, tomando lugar no "diz-se", distribuindo-se, dispersando-se na espessura da linguagem. Segundo um paradoxo constante em Foucault, a linguagem só se agrega a um corpus para ser um meio de distribuição ou de dispersão de enunciados, a regra de uma "família" naturalmente dispersada" (Deleuze 1988: 29).

60. Deleuze, ao analisar a obra de Foucault, explica que o "saber não é ciência, nem mesmo conhecimento; ele tem por objeto as multiplicidades anteriormente definidas, ou melhor, a multiplicidade exata que ele mesmo descreve, com seus pontos singulares, seus lugares e suas funções" (Deleuze 1988: 30). A busca de um ponto sensivel estaria exatamente nessas singularidades, nos seus lugares e suas funções que somente poderiam ser localizadas, encontradas e demonstradas em algum sujeito e não fora dele. Descrever as multiplicidades de 
pontos singulares, seus lugares e suas funções, pressupõe um aprendizado de escrita [e de leitura]. No entanto, se esse sujeito não for capaz de redigir um texto dentro de práticas discursivas reconhecidas institucionalmente, por mais sensivel que ele seja, por mais singularidades que ele possa apresentar, por maior que seja o conjunto (ou estoque) de enunciados que ele for capaz de colecionar, tudo isso seria em vão. Todos esses enunciados seriam apagados com a morte desse sujeito. Seria como queimar uma biblioteca ou apagar a memória de um arquivo de computador. Ele não poderia se constituir a si próprio como um dado, ou mesmo em um "monumento de arquivo", ele poderia, no máximo, deixar alguns "documentos" que serviriam de razões para os "outros", que auxiliariam na constituição de circunstâncias para novos sujeitos.

61. O aprendizado de escrita pressupõe o uso de uma língua, de uma gramática (Derrida 2006), o domínio de sinais e impressões que deixam uma marca sobre uma superfície, um registro que pode transitar de um sujeito para o outro. O trânsito sugere a abertura de caminhos, espaços por onde se pode transitar. $\mathrm{O}$ caminho em si é vazio [a não ser quando se encontra uma pedra no meio do caminho, mas isso já seria outra história]. Ele não deixa de ser uma via de acesso, comunicação entre lugares [entre São Paulo e um "Belo Horizonte”, por exemplo]. De acordo com Derrida, somente " $a$ ausência pura - não a ausência disto ou daquilo mas a ausência de tudo em que se anuncia toda a presença - pode inspirar, ou por outras palawras trabalhar, e depois fazer trabalhar" (Derrida 2005c: 20). Assim, o livro puro seria o livro sobre "nada" [deve-se reter essa informação] em que a passagem à determinação da obra é o disfarce da origem [distração ou a traição da origem], uma origem do Livro total que foi obsessão de outras imaginações. A angústia da escritura repousa sobre a angústia de um sopro ou palavra, uma responsabilidade de que "falar mete-me medo, porque, nunca dizendo o suficiente, sempre digo também demasiado" (idem, p.21). Seria essa a responsabilidade evitada e temida pelo artista Marcel Duchamp [e, claro, por
Sócrates]? A escritura revela em um jogo de repetições, um projeto de tradição infinita, quer ele se realize ou não. É preciso reconhecêlo e respeitá-lo no seu sentido de projeto. Só se compreende um "querer-escrever" a partir de um voluntarismo. "Na sua relação ao ser, o quererescrever pretenderia ser a única saída para fora da afecção. (...) Ser afetado é ser finito: escrever seria ainda usar de manha em relação à finitude, e querer atingir o ser fora do sendo, o ser que não poderia ser nem afetar-me ele próprio. Seria querer esquecer a diferença: esquecer a escritura na palavra presente, tida como viva e pura" (ibidem, p.27).

62. O uso de metáforas espaciais para refletir a linguagem revela um sentido de construção e arquitetura. A ordem das formas e seus lugares fazem referência a um espaço morfológico e geométrico que denunciam um imaginário relativo às nossas percepções. A "travessia" da escritura supõe um deslocamento entre a palavra perdida e a palavra prometida. Entre dois lugares existe sempre um terceiro ponto que denuncia uma fronteira. Quem escreve abandona sua escritura em um caminho [a pedra volta a se insinuar no caminho] para dar passagem a um "outro". Ela, a escritura, se transfigura em um caminho [as pedras são colocadas pelos poetas]. O escritor é simultaneamente construtor sentinela [pois ele é o responsável por tudo aquilo deixado ou construído no caminho] e o primeiro passante. A vigília é necessária, pois se trata de uma paixão de origem que quer ser inscrita. "Abandonar a escritura é só lá estar para lhe dar passagem, para ser o elemento diáfano da sua procissão: tudo e nada. Em relação à obra, o escritor é ao mesmo tempo tudo e nada. Como Deus" (Derrida 2005a: 61). Paixão de origem, mas não necessariamente a origem. $\mathrm{O}$ "como" revela a propriedade da linguagem ou a sua "impropriedade" original. A origem está perdida e a utilização da linguagem é desde o início, um processo de apropriação ou mesmo um "roubo". ${ }^{11}$ Se a

(11) Apenas "o sonhador inventa a sua própria gramática" (Derrida 2005c: 196). Quanto ao roubo, relembremos a obra "Corpus Delicti", de Jac Leirner, constituída de objetos "roubados" [ou, mais precisamente, "furtados"]. 
busca por uma origem revela uma metafísica, a superstição está na essência de nossa relação com o nome "Deus". Se a coleção de objetos revela uma paixão de origem, ou está inevitavelmente associada à morte, talvez seja porque a morte se inscreve em nós desde a origem, desde o nascimento "e esta desapropriação produziu-se desde a origem, é o próprio movimento da origem, do nascimento como morte" (idem, p.151). A morte passeia entre as letras [como em sword e word ou mesmo snake e naked] pois a linguagem é sempre mais rica que o saber. Talvez a morte seja apenas mais uma representação, [os limites da representação: nascimento/morte], pois aquele que morre não morre para si, morre para os outros. A vida se protege da morte pela repetição, é uma das teorias de Derrida.

63. "Toda a saída para fora do livro faz-se no próprio livro. Não há dúvida de que o fim da escritura se situa para lá da escritura" (Derrida 2005c: 68). Somente o escrito faz existir um nome, nomeia e se deixa nomear. Na linguagem, as palavras são coisas e o tempo revela o espaçamento para uma possibilidade simbólica. O tempo é a própria economia de uma escrita (idem, p.220). Não resta dúvida de que Duchamp, ao afirmar que sua matéria-prima era o tempo estava deixando a evidência de que no seu trabalho se instalava o "tempo" na praxis da linguagem artística. "O interesse da psicanálise pela lingüistica pressupõe que se transgrida o sentido habitual da palaura linguagem" (ibidem, p.212). Pois no jogo da linguagem todo o signo pode ser usado em níveis, em funções e configurações que não são prescritas na sua essência, mas nascem de jogos da "diferença", preconiza Derrida. De acordo com esse filósofo, o momento da diferença se estabelece na leitura, na interpretação, no destino de uma representação. Se a escrita, de Platão a Freud, é vista como técnica auxiliar da memória e não como a memória em si, é entre a escritura e a leitura que se estabelece a abertura. "O percebido só se dá a ler no passado, abaixo da percepção e depois dela" (p.219). Para Freud, todo pensamento nada mais é do que um caminho desviado (p.220) [e o que seria uma pedra no meio de um caminho desviado?].
64. "Só somos escritos escrevendo, pela instância em nós que sempre já vigia a percepção, quer ela seja interna quer externa" (Derrida 2005a: 222). Se a escritura é a cena da história e o próprio jogo do mundo, sempre que se está escrevendo há o risco de se pensar sem se ter pensado, dizer sem se dizer, ser escrito e ao mesmo tempo apagado, metaforizado, o próprio sujeito designado a indicar relações intramundanas, portanto, ele mesmo ser representado (idem, p.224-225 - adaptado). A "arqui-escritura" é descrita por Derrida como um processo de desaparição: do presente, e, portanto, do sujeito, do seu próprio e do seu nome próprio. Esse desaparecimento é a própria morte, o traço, a ameaça ou a angústia da sua desaparição irremediável, de um sujeito (consciente ou inconsciente), filho de Deus (ibidem, p.226), portanto, filho da Morte. Nessa cena, a vida é que se revela como o verdadeiro acontecimento, a forma exterior de uma ruptura e de um redobramento (ibidem, p.229). A escritura joga com todas essas circunstâncias.

65. A coerência na contradição pode exprimir a força de um desejo. $\mathrm{O}$ desejo, originariamente procura um centro. $\mathrm{Na}$ ausência de centro ou de origem, tudo se torna discurso [ou "percurso"], obviamente inscrito em um texto, uma escritura. "A ausência de significado transcendental amplia indefinidamente o campo e o jogo da significação" (Derrida 2005a: 232). [A natureza do campo é de um jogo de substituições infinitas no fechamento de um conjunto finito. A sua totalização se revela ora inútil, ora impossível, diz Derrida mais adiante, p.244]. (...) "Para designar esta produção, seria de certo modo ingênuo referir um acontecimento, uma doutrina ou o nome de um autor. Esta produção pertence sem dúvida à totalidade de uma época, que é a nossa, mas ela sempre já começou a anunciar-se e a trabalhar" (idem, p.232). Em um esquema formal aplicado às ciências humanas, é a Etnologia que surge como mais um elemento que "acolhe em seu discurso as premissas do etnocentrismo [a princípio, inevitavelmente eurocêntrico] no próprio momento em que o denuncia" (ibidem, p.235). "A qualidade e a fecundidade de um discurso medem-se talvez pelo 
rigor crítico com que é pensada essa relação com a história da Metafísica e aos conceitos herdados. Trata-se ai de uma relação crítica à linguagem das ciências humanas e de uma responsabilidade crítica do discurso. Trata-se de colocar expressa e sistematicamente o problema do estatuto do discurso que vai buscar a uma herança os recursos necessários para a des-construção dessa mesma herança. Problema de economia e de estratégia" (ibidem).

66. "A superabundância do significante [existem mais significantes do que significados, no esquema da movimentação de significação], o seu caráter suplementar resulta, portanto de uma finitude, isto é, de uma falta [ou ausência] que deve ser suprida" (Derrida 2005a: 246). A sintaxe se manifesta rapidamente permitindo a apreensão de uma forma gramatical, o que não remete necessariamente a um fechamento das possibilidades de significação. Porque existe um suplemento [o termo é enfatizado por Derrida] extra de significantes é que existe a abertura da linguagem, a saída, que trabalha os acasos e as descontinuidades, colocando em parênteses a história [e as ciências humanas]. "Tensão do jogo com a história, tensão do jogo com a presença. A presença de um elemento é sempre uma referência significante e substitutiva inscrita num sistema de diferenças e o movimento de uma cadeia. O jogo é sempre jogo de ausência e de presença, mas se o quisermos pensar radicalmente, é preciso pensá-lo antes da alternativa da presença e da ausência; é preciso pensar o ser como presença ou ausência a partir da possibilidade do jogo e não inversamente" (idem, p.248).

67. Trata-se de um jogo sem segurança, caso contrário não seria um jogo verdadeiro, seria uma fraude. Portanto, as ciências humanas lidam com questões inconciliáveis e simultâneas: a possibilidade de duas interpretações da interpretação, da estrutura, do signo e do próprio jogo. "Uma procura decifrar uma verdade ou uma origem que escapam ao jogo e à ordem do signo, e sente como um exílio a necessidade da interpretação. A outra, que já não está voltada para a origem, afirma o jogo e procura superar o homem e o humanismo, sendo o nome do homem o nome desse ser que, através da história da Metafísica ou da onto-teologia, isto é, da totalidade da sua história, sonhou a presença plena, o fundamento tranqüilizador, a origem e o fim do jogo" (Derrida 2005a: 249). A conciliação do inconciliável é uma partilha da abertura [consciente e inconsciente] que acontece na escritura independente das vontades e intenções em um devir em constante movimento [um devir sempre "em trânsito"]. Para Derrida, no campo da historicidade, a escolha parece bem frágil, pois o "ainda inominável que se anuncia e que só pode fazê-lo, como é necessário cada vez que se efetua um nascimento, sob a espécie da não-espécie, sob a forma informe, muda, infante e terrificante da monstruosidade" (idem).

68. Post-Scriptum: qual é a história da concepção? A resposta está na literalidade da pergunta que está na escritura inicial. No campo das escavações arqueológicas o segredo são as cinzas do arquivo, o começo da fé. Só podemos sonhar, a posteriori. A memória fiel de uma singularidade está entregue a um fantasma. Tudo não passaria de uma ficção? "Perguntar-nos-emos sempre o que foi possivel, neste mal de arquivo, arder. Perguntar-nos-emos sempre, para partilhar com compaixão este mal de arquivo, o que queimou de suas paixões secretas, de sua correspondência, de sua "vida". Queimar sem ele, sem resto e sem saber. Sem resposta possível, espectral ou não, aquém ou além de uma repressão, na outra borda do recalque, o originário ou o secundário, sem um nome, sem o menor sintoma e nem mesmo uma cinza" (Derrida 2001: 125-129).

69. The end is [always] the beginning. 
BRAGA, G.B. Fragments to file a collection. Revista do Museu de Arqueologia e Etnologia, São Paulo, 19: 309-335, 2009.

Abstract: This article presents a series of thoughts about "collections", "collectables" and the people called "collector". Those thoughts are mainly influenced on the idea of "desconstruction", from the philosopher Jacques Derrida.

Keywords: Collection - Collectables - Collector - Archive - Cognitive archaeology - Derrida - Language construction narratives - Contemporary art - Post scriptum.

\section{Referências bibliográficas}

BAUDRILLARD, J.

1993 O sistema dos objetos. Tradução: Zulmira Ribeiro Tavares. Revisão de tradução: Geraldo Gerson de Souza e Mary Amazonas Leite de Barros. São Paulo: Editora Perspectiva.

2002 A troca impossivel. Tradução: Cristina Lacerda e Teresa Dias Carneiro da Cunha. Rio de Janeiro: Nova Fronteira.

2003 De um fragmento ao outro. Tradução: Guilherme João de Freitas Teixeira. São Paulo: Zouk. [Entrevista concedida a François L'Yvonnet].

2006 As estratégias fatais. Tradução de Ana Maria Scherer. Rio de Janeiro: Rocco.

2007 Senhas. Tradução de Maria Helena Kühner. - $2^{\mathrm{a}}$ ed. Rio de Janeiro: DIFEL.

BERGSON, $\mathrm{H}$.

1999 Matéria e memória: ensaio sobre a relação do corpo com o espírito. São Paulo: Martins Fontes. (Coleção Tópicos).

BLOOM, $\mathrm{H}$.

1995 O cânone ocidental: os livros e a escola do tempo. Tradução: Marcos Santarrita. Rio de Janeiro: Objetiva.

2005 Onde encontrar a sabedoria? Tradução de José Roberto O'Shea. Rio de Janeiro: Objetiva.

BRAGA, G.B.

2008 A tese na [da] caixa preta. Tese de doutorado. Escola de Comunicações e Artes da Universidade de São Paulo. São Paulo.

CABANNE, P.

2002 Marcel Duchamp: engenheiro do tempo perdido. Tradução Paulo José Amaral;
Revisão: Plínio Martins Filho e Roney Cytrynowixz. São Paulo: Perspectiva.

(Segunda edição, segunda reimpressão).

CERTEAU, M. de

1994 A invenção do cotidiano: 1. Artes de fazer. Tradução de Ephraim Ferreira Alves. Petrópolis, RJ: Vozes.

CHOMSKY, N.

2005 Novos horizontes no estudo da linguagem e da mente. Tradução: Marco Antônio Sant'Anna. São Paulo: Editora UNESP.

DANTO, A. C.

2005 A transfiguração do lugar-comum: uma filosofia da arte. Tradução: Vera Pereira. São Paulo: Cosac \& Naify. [Título original: The transfiguration of commonplace: a philosophy of art - 1981].

DELEUZE, G.

1988 Foulcault. Tradução de Claudia Sant'Anna Martins e revisão de Renato Janine Ribeiro. São Paulo: Brasiliense, 1988. (quinta reimpressão, 2005).

1999 Bergsonismo. Tradução de Luiz B. L. Orlandi. São Paulo: Ed. 34. (Coleção TRANS).

2001 Empirismo e subjetividade: ensaio sobre a natureza humana segundo Hume. Tradução de Luiz B. L. Orlandi. São Paulo: Ed. 34. (Coleção TRANS).

DERRIDA, J.

1990 Do espirito: Heidegger e a questão. Tradução: Constança Marcondes Cesar. Campinas, SP: Papirus.

1995 Khôra. Tradução: Nícia Adan Bonatti. Campinas, SP: Papirus. 
1996 Archive Fever: a Freudian impression. Translated by Eric Prenowitz. Chicago/ London: The University of Chicago Press.

2001 Mal de Arquivo: uma impressão freudiana. Tradução: Cláudia de Moraes Rego. Rio de Janeiro: Relume Dumará.

2004 Papel-máquina. Tradução: Evandro Nascimento. São Paulo: Estação Liberdade.

2005a A escritura e a diferença. Tradução: Maria Beatriz Marques Nizza da Silva. São Paulo: Perspectiva (Debates; 49). [Primeira impressão da terceira edição de 2002].

2005b A farmácia de Platão. Tradução: Rogério da Costa. São Paulo: Iluminuras.

2005c Gêneses, genealogias, gêneros e o gênio. Tradução do francês: Eliane Lisboa. Porto Alegre: Sulina.

2006 Gramatologia. Tradução: Miriam Chnaiderman e Renato Janine Ribeiro. São Paulo: Perspectiva [Estudos; 16]. [2a reimpr. Da 2a ed. de 2000].

\section{EAGLETON, T.}

2000 The Idea of Culture. London: Blackwell Publishing.

2005 A idéia de Cultura. Tradução: Sandra Castello Branco. Revisão técnica: Cezar Mortari. São Paulo: Editora UNESP.

FOUCAULT, M.

1979 Microfísica do Poder. Organização e tradução: Roberto Machado. Rio de Janeiro: Edições Graal.

1989 Isto não é um cachimbo. São Paulo: Paz e Terra.
FLUSSER, V.

2002 Da religiosidade: a literatura e o senso de realidade. São Paulo: Escrituras. [Coleção ensaios transversais].

HABERMAS, J.

2004 A ética da discussão e a questão da verdade. Tradução: Marcelo Brandão Cipolla. São Paulo: Martins Fontes.

MALRAUX, A.

2000 O museu imaginário. Tradução: Isabel Saint-Aubyn. Lisboa - Porturgal: Edições 70. (Título original: Le Musée Imaginaire Éditions Gallimard, 1965).

MERLEAU-PONTY, M.

2003 O visível e o invisível. Tradução de José Artur Gianotti e Armando Mora. São Paulo: Perspectiva. (Quarta edição).

2004 O olho e o espírito: seguido de A linguagem indireta e as vozes do silêncio e A dúvida de Cézanne. Tradução de Paulo Neves e Maria Ermantina Galvão Gomes Pereira. Prefácio: Cláudio Lefort; posfácio: Alberto Tassinari. São Paulo: Cosac \& Naify.

RICOEUR, P.

2008 Hermenêutica e ideologias. Organização, tradução e apresentação: Hilton Japiassu. Petrópolis: Vozes.

TOMKINS, C.

2005 Duchamp: uma biografia. Tradução de Maria Thereza de Rezende Costa. Prefácio de Paulo Venâncio Filho. São Paulo: Cosac \& Naify. 